Cavga, S. ve Eyüp, B. (2021). Şermin Yaşar'ın çocuk kitaplarındaki eğitsel iletilerin incelenmesi. Ana Dili Eğitimi Dergisi, 9(4), 1400-1420.

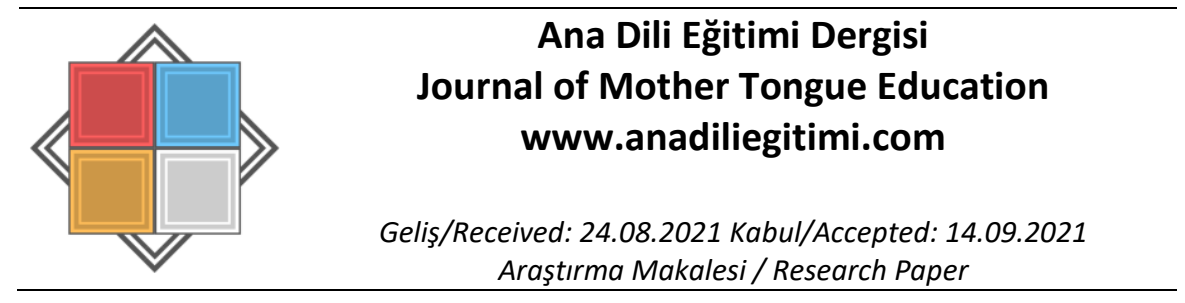

\title{
Şermin Yaşar'ın Çocuk Kitaplarındaki Eğitsel Illetilerin İncelenmesi
}

\author{
Sema CAVGA* \\ Bircan EYÜP ${ }^{* *}$
}

Öz

Bu çalışmanın amacı, günümüz çocuk edebiyatı yazarlarından Şermin Yaşar'ın çocuk kitaplarındaki eğitsel iletilerin belirlenmesidir. Çalışma nitel araştırma desenlerinden durum çalışması olarak tasarlanmıştır. Veri kaynağı Şermin Yaşar'ın 'Dedemin Bakkalı', 'Abartma Tozu', 'Oh Ne Ala Memleket' ve 'Babaannem Geri Döndü' adlı çocuk kitaplarından oluşmaktadır. Veriler doküman incelemesi yöntemi ile toplanıp içerik analizi ile analiz edilmiştir. Eğitsel iletiler kişisel, toplumsal, ulusal, evrensel, dinî gelişimi ve çevre bilinci gelişimini desteklemeye yönelik olmak üzere altı başlık altında incelenmiştir. Araştırma sonucunda 'Dedemin Bakkalı' kitabında 91, 'Abartma Tozu'nda 77, 'Oh Ne Ala Memleket'te 72 ve 'Babaannem Geri Döndü' adlı kitapta 65 farklı eğitsel ileti tespit edilmiştir. En çok ileti 'Dedemin Bakkalı', en az ileti 'Abartma Tozu' kitabında belirlenmiştir. 'Babaannem Geri Döndü' kitabında toplumsal, diğer üç kitapta kişisel gelişimi destekleyen iletilerin çoğunlukta olduğu görülmüştür. İletilerin ağılıklı olarak dolaylı aktarıldığı tespit edilmiştir. Ayrıca iletilerin Millî Eğitim Bakanlığınca hazırlanan ders programlarında yetiştirilmesi hedeflenen bireylerde olması istenilen özelliklerle de benzerlik gösterdiği belirlenmiştir.

Anahtar Kelimeler: Çocuk edebiyatı, çocuk kitabı, ileti, eğitsel ileti, Şermin Yaşar

\begin{abstract}
Examination of Educational Messages in Şermin Yaşar's Children's Books Abstract

This study aimed to examine the educational messages in the children's books of Şermin Yaşar, a children's literature author. The study was designed as a case study. The data consisted of Şermin Yaşar's children's books named 'Dedemin Bakkalı', 'Abartma Tozu', 'Oh Ne Ala Memleket' and 'Babaannem Geri Döndü'. The data were collected through document analysis and analyzed by doing content analysis. Educational messages were examined under six categories: personal, social, national, universal, religious and environmental awareness development. It was concluded that there were 91 educational messages in 'Dedemin Bakkalı', 77 in 'Abartma Tozu', 72 in 'Oh Ne Ala Memleket' and 65 in 'Babaannem Geri Döndü'. While the highest number of educational message was found in 'Dedemin Bakkalı', 'Abartma Tozu' was identified with the lowest number of educational messages. It was determined that the messages were mainly narrated indirectly. It was also determined that the messages were similar to the characteristics desired to exist in the individuals educated in the curriculum prepared by the Ministry of National Education.
\end{abstract}

Keywords: Children's literature, children's book, message, educational message, Şermin Yaşar

\section{Giriş}

Çocukluk dönemi; bilişsel, sosyal ve duygusal yönden temel becerilerin edinildiği ve algıların çok açık olduğu bir dönemdir. Bebeklikten ergenliğe kadar devam eden bu süreçte çocuk; öz bakım becerilerini kazanır, dili edinir, sosyalleşir, somut ve soyut düşünme becerilerini kazanır, çevreyi ve

\footnotetext{
* Türkçe Öğretmeni, Millî Eğitim Bakanlığı, Konya, sema_cavga@hotmail.com, ORCID: orcid.org/0000-00016185-5107

** Dr. Öğr. Üyesi, Trabzon Üniversitesi, Fatih Eğitim Fakültesi, Türkçe ve Sosyal Bilimler Eğitimi Bölümü, Trabzon, bircaneyp@gmail.com, ORCID: orcid.org/0000-0001-8061-1159
} 
kendini keşfeder. Bu süreçte ailesi, çevresi, öğretmenleri; okudukları, dinledikleri, izledikleri çocuğun duygu ve düşünce dünyasını şekillendirir. Nitekim "bireylerin sağıılı bir kişilik oluşturması, yeteneklerini en verimli şekilde geliştirebilmesi ve toplumda işlevsel olabilmesi çocukluk yıllarında kazanılan deneyimlere dayanır. Bu deneyimlerin önemli bir kısmı çocuğun eğitimi ile gerçekleşir" (Aral ve Baran, 2011, s. 4). Bu dönemde çocuğun eğitiminde önemli etkenlerden biri de kitaplardır. Çocukların kitaplarla tanıştıııması, çocuklarla okuma etkinlikleri düzenlenmesi gelişimleri adına oldukça önemlidir. Çocukların olayları, durumları anlama ve yorumlama biçimleri kısacası dünyayı algılayış biçimleri yetişkinlerinkinden farklıdır. Bu durum; çocukların duygu ve düşünce yapısını göz önünde bulunduran, onlara yönelik yazılan kitapları yani çocuk edebiyatını ön plana çıkarmaktadır.

Çocuk edebiyatı "çocukların hayatı kavramasına yardımcı olacak, hayal gücünü geliştirici, okuma sevgisini aşılayan, eğitici bir edebiyat türü, çocuk yazını" şeklinde tanımlanmaktadır (Türk Dil Kurumu [TDK], 2021). Sever (2019, s. 7) ise çocuk edebiyatını "erken çocukluk döneminden başlayıp ergenlik dönemini de kapsayan bir yaşam evresinde, çocukların dil gelişimi ve anlam düzeylerine uygun olarak duygu ve düşünce dünyalarını sanatsal niteliği olan dilsel ve görsel iletilerle zenginleştiren, beğeni düzeylerini yükselten ürünlerin genel adı" olarak tanımlar. Her iki tanımdan da anlaşılacağı üzere çocuk edebiyatı; çocukların duygu ve düşünce dünyalarını zenginleştirmede önemli rol oynar. Aynı zamanda çocuğa 'zenginleştirilmiş bir dil çevresi' sunarak çocuğun dil gelişimine katkı sağlar, dil bilinci ve duyarlılı̆ı kazanmasına yardımcı olur, sözcük dağarcığını geliştirir. Böylelikle çocuk kendini daha doğru ve etkili bir şekilde ifade eder. Çocukların iyi ve kötüyü ayırt etmesini, toplum tarafından benimsenen tutum, değer ve davranışları fark etmesini sağlar. Bireylerin toplum içindeki rollerini fark edip kendilerine bir yol çizmelerine yardımcı olur. Çocuğa çevresinden farklı yaşam kesitleri sunarak yaşamdaki sorunları ve bu sorunlara dair çözüm yollarını fark ettirir. Farklı ülkeleri, kültürleri tanıma fırsatı (Sever, 2019) sunduğu gibi çocuğun kendi kültürünü, tarihini, dilini de öğrenmesine olanak sağlar. Çocuğa hiç bilmediği dünyaların kapılarını aralar; farklı meslekleri, spor ve sanat dallarını tanıtır. Böylece çocuğun ilgi alanlarını ve sahip olduğu becerileri keşfetmesine yardımcı olur. Yeni şeyleri anlama ve öğrenme isteğini artııı. Ayrıca çocuklara zorluklardan yılmamayı, pes etmemeyi, çalışmayı, başarmayı öğretir ve onları geleceğe hazırlar (Yardımcı ve Tuncer, 2002). Kısacası çocuk edebiyatı, çocuğun kendini ve hayatı keşfetme yolculuğunda bir kılavuzdur.

Günümüzde çocuk edebiyatında üç temel kavramdan söz edilmektedir. Bunlar: 'çocuk bakışı', 'çocuğa görelik' ve 'çocuk gerçekliği'dir (Şirin, 2019). Hedef kitlesi çocuk olduğu için çocuk edebiyatı, konularını çoğunlukla çocuğun doğal çevresinden alır. Bu sebeple de dil, anlatım, sözcük seçimi, seviye ve konu gibi hususlar açısından çocuğa göredir. Çocuk gerçekliğinden hareketle ve çocuğa göre oluşturulan bu edebiyatın esas amacı da çocuğun okuma ilgisini artırmaktır (Dilidüzgün, 2004). Bu bakımdan çocuk edebiyatı ürünleri çocuğun okuma kültürü edinmesinde işlevsel bir role sahiptir. Okuma kültürü Sever $(2013$, s. 9) tarafından "yazılı kültür ürünlerinin dünyasıyla tanışmış; tanıştığı bu dünyanın kendisine sunduğu iletileri paylaşma, sınama, sorgulama yeterliğine ulaşmış; bunların sunduğu olanaklarla yaşamayı alışkanlık hâline getirmiş bireylerin edinmiş olduğu kazanımlar bütünü" olarak ifade edilir. Bunun için de çocuklara küçük yaşta okuma alışkanlığı kazandırılmalıdır. Okuma alışanlığı, "bireyin okumayı bir ihtiyaç ve zevk kaynağı olarak algılayıp bu eylemi yaşam boyu sürekli ve düzenli bir biçimde, eleştirici bir nitelikte gerçekleştirmesidir" (Doğanay, 2001, s. 41'den aktaran Suna, 2006, s. 14). Okuma alışkanlığı kazanmanın yolu okuma sevgisinden geçer. Bu nedenle ilk okunan kitaplar bu açıdan oldukça önemlidir (Arıcı, 2008). Zira çocuğun ilk yıllarında kitapla tanışması ve tanıştığı bu kitaplar onun hayatının tamamını etkiler (Tanju, 2010). Nitekim okuma becerisi ve alışkanlığı kazanan birey; öğrenim hayatında, meslek hayatında (Kavcar, Oğuzkan ve Sever, 2005) ve kendi özel ve sosyal hayatında da daha başarılı olur. Ancak çocuk kitaplarının; çocuğun kitaba ilgisinin artmasını, kitapla etkili iletişim kurmasını, kitap okumayı sevmesini ve böylece okuma kültürü edinmesini sağlayabilmesi için bazı biçimsel ve eğitsel özelliklere sahip olması gerekir (Canlı ve Aslan, 2018). Öncelikle çocuğun kitaba yönelik ilgisinin ve merakının oluşmasında kitabın biçimsel/dış yapı özellikleri etkilidir. Bunlar; resim, boyut, cilt, harf, punto, kapak, kâğıt ve sayfa düzeni gibi özelliklerden oluşmaktadır (Yılmaz, 2016). Çocuğun kitapla etkili bir iletişim kurup yeni kitaplar okuma isteği duymasını sağlayan özellikler ise kitabın konu, tema/izlek, plan, ileti, karakter, dil ve anlatım gibi içerik/iç yapı özellikleridir (Canlı ve Aslan, 2018). 
Çocuk kitapları çocuk edebiyatının temel ilkelerinden, içerik özelliklerinden biri olan iletiler aracılığıyla çocuk eğitimine katkı sağlar. İleti "okuma eylemi sonunda yazarın okura vermek istediği düşünce" (Yılmaz, 2016, s. 81) olarak tanımlanır. Her kitapta olduğu gibi çocuk kitaplarında da aktarılmak istenen iletiler vardır. Her kitap aynı amaçla yazılmaz, her metnin kendine özgü bir dış görünüşü ve yazılış biçimi vardır. Bir hekim reçetesi, yemek tarifi ya da bir şiir hepsinin farklı biçimsel özellikleri vardır. Metinleri sınıflandırmak için metnin tonu, tipi ve türü olmak üzere üç ölçüt kullanılır. Metnin türü, tipi ya da tonunu belirlemek için metinler farklı açılardan değerlendirilir ve aynı özellikleri gösteren metinlerle bir sınıflandırma yapılır. Ton, yazarın, okuyucunun üzerinde oluşturmak istediği ruhsal etkilemedir. Metindeki tonlama, yazarın niyetlerini, duygularını ve duyarlılıklarını konuyu ele alma biçimi ile aktarmasıdır. Tip, bazı ortak yönlerle sınıflandırılmış metnin genel özelliğini belirtir. Tür ise metnin anlatım biçimi, sözceleme durumu, okurla olan etkileşimi gibi bazı ayırt edici özeliklerle sınıflandırılmasıdır (Günay, 2003). Bu üç özellik iletilerin aktarılış biçimini de etkilemektedir.

Çocuklara yönelik kitaplar öğretici ve yazınsal metinler olarak ikiye ayrılmaktadır; öğretme amaçlı metinlerde amaç bilgi aktarmakken yazınsal amaçlı metinlerde çocuklarda sezme, duyma, düşünme becerilerini geliştirmek ve çeşitli duyarlııklar kazandırmaktır. Bu yüzden bu metinlerin iletileri aktarış biçimleri farklııı gösterir (Sever, 2019). Yazınsal veya öğretici metinler, iletilerin aktarım biçiminin doğrudan ya da dolaylı olması yönünden belirleyicidir. Doğrudan iletiler okuyucuya hiçbir aracı kullanılmadan açıkça verilirken dolaylı iletiler doğrudan verilmeyip metin içerisinde okuyucunun çıkarımları ile bulacağı iletilerdir. Bu noktada çocuk edebiyatı ürünlerinin amacının öğretmek olmadığını ifade eden Canlı ve Aslan $(2018$, s. 816) da iletilerin örtük ve eserin güzelduyusal özelliği ile kaynaşmış, bütünleşmiş olarak verilmesinin gerekliliğini vurgular. Ancak bu iletileri aktarırken çocuklarla üst perdeden konuşan, çocuklara sürekli nasihat eden, eğlendirmeyen, meraklandırmayan kitaplar doğallıktan uzaklaşır. "Bu doğallığı, içtenliği ve yalınlığı sağlayabilmenin tek yolu, çocuğun dünyasını 'çocuğun dili' ile söylemektir. 'Çocuğun dili ile söylemek', çocuğun gözü ile görebilmeyi, çocuğun aklı ile düşünebilmeyi, çocuğun mantığı ile sorgulayabilmeyi gerektirir" (Taşdelen, 2005, s. 324). Aksi takdirde verilmek istenen iletinin ya da iletilerin çocuk nezdinde bir anlamı olmayacaktır.

Hedef kitlesine bir şeyler söylemek için kurgusunu hazırlayan her yazarın bir ana iletisi vardır. Ancak yazınsal nitelikli metinlerde bu ana iletiyi destekleyen yardımcı iletiler de olabilir. Yani bir metin bazen birden fazla şey söyleyebilir (Yılmaz, 2016). İster bir adet ister birden fazla iletisi olsun bu metinlerdeki iletiler çocuklara yönelik olmalı ve eğitsel özellikler taşımalıdır. Bu iletilerin ne söylediği, neyle ilgili olduğu oldukça önemlidir. Zira çocuk, edebiyatla sadece hoşça vakit geçirmemeli aynı zamanda iyiye, güzele, doğruya yöneltilmelidir. Ancak çocuğun psikolojik, bilişsel ve sosyal gelişimini göz önünde bulunduran bazı çocuk kitapları bu iletileri eğitim aracı olarak görürken bazı çocuk kitapları eğitsellikten tamamen uzaktır. Kitaplar; çocukları yanlış yargılara, boş inançlara, kaderciliğe, saldırganlığa, ırkçılığa, düşmanlığa yöneltmemeli ve onlara öç alma gibi duygular aşılamamalıdır (Tür ve Turla, 2005, aktaran Akçay ve Baş, 2015). Kişilerin özel durumlarını küçümsememeli, mutsuz aileleri konu edinmemeli, bireysel ve toplumsal şiddet anlatımları içermemelidir. Cinsel içerikli küfür ve sözlere yer verilmemeli, duygu sömürüsü yapılmamalıdır (Çınar, 2009). Çocuk kitapları, çocuğun kendi potansiyelini fark etmesini sağlayacak, ona olumlu duygu ve değerler katacak iletiler içermelidir. Fakat burada önemli olan kitapların mesaj verme kaygısı taşımadan bu iletileri çocuklara sunabilmesidir. Aksi durum söz konusu olduğunda çocuk okur kitaptan uzaklaşabilmektedir. Bu açılardan bakıldığında çocuklar için yazılmış olan kitaplarda sunulan iletiler oldukça önem kazanmaktadır. Gelişim evrelerinin en önemli döneminde olan çocukların bu kitaplardan çıkaracakları mesajlar hayatlarının ileriki aşamalarında belirleyici roller oynayabilir. Bu bakımdan çocukların okudukları kitaplarda yer alan iletilerin tespit edilmesi çocukların hangi iletilerle karşılaştıklarını görmek açısından hem eğitimcilere hem anne babalara hem de alanda çalışanlara yol göstermesi sebebiyle değerli görülmektedir.

Alanyazın taraması yapıldığında çocuk edebiyatı alanında eser vermiş Muzaffer İzgü (Köse, 2011), Hidayet Karakuş (Kaplan, 2013), Samed Behrengi (Akçay ve Baş, 2015), Mavisel Yener (Cesur ve Baş, 2015), Sevim Ak (Uzuner-Yurt ve Şimşek, 2016), Sevinç Kuşoğlu (Karahanoğlu, 2017), Çetin Öner (Kuru, 2018), Koray Avcı Çakman (Kavak ve Baş, 2018), Aytül Akal (Tekin ve Büyükikiz, 2019), ibrahim Örs (Acele, 2019) ve Nur içözü (Gül, 2019) gibi yazarların kitaplarını eğitsel açılardan inceleyen çalışmaların mevcut olduğu görülmüştür. Ancak günümüzün tanınmış yazarlarından, çocuk edebiyatı 
alanında eserler veren, çocuğu çocuk dilinden anlatan, kitaplarını okuyan çocukları ince mizah anlayışıyla güldüren ve güldürürken düşündüren Şermin Yaşar'ın kitaplarını bu açıdan ele alan herhangi bir çalışmaya rastlanmamıştır. Oysaki Yaşar günümüz çocukları tarafından çokça okunan bir yazardır. Ayrıca Yaşar'ın sosyal medyada 'Kelimelerin Ardı' adında kelimelerin anlamını ve nereden geldiklerine dair çocuklara yönelik hazırlamış olduğu videoların bulunması ve bu videoların EBA'da da yer alması çocuklar ve veliler arasında tanınırlığını artırmaktadır. Zira bugün okullarda çalan 'Gelecek Biziz' adlı şarkının sözlerinin de Yaşar'a ait olması öğrenciler arasında daha çok tanınmasına katkı sağlamıştır. Tüm bunlarla birlikte Taşdelen (2005) çocuk edebiyatçısının annelik hislerinin gelişmiş olmasını, çocuk edebiyatının zeminini annelik hâlinin oluşturduğunu söylemektedir. Bu da bugün kendi çocuklarından hareketle annelerle kendi annelik deneyimlerini de paylaşan Şermin Yaşar'ın kitaplarında çocuklara hangi eğitsel iletileri aktardığını ve bu iletileri nasıl aktardığını belirlemenin alanyazına katkı sağlayacağını göstermektedir.

Bu çalışmada, Şermin Yaşar'ın 'Dedemin Bakkalı', 'Abartma Tozu', 'Oh Ne Ala Memleket' ve 'Babaannem Geri Döndü' adlı kitaplarında yer alan eğitsel iletilerin incelenmesi amaçlanmıştır. Bu doğrultuda aşağıdaki sorulara cevap aranmıştır:

1. Şermin Yaşar'ın çocuk kitaplarında yer alan kişisel gelişimi destekleyen iletiler nelerdir?

2. Şermin Yaşar'ın çocuk kitaplarında yer alan toplumsal gelişimi destekleyen iletiler nelerdir?

3. Şermin Yaşar'ın çocuk kitaplarında yer alan ulusal gelişimi destekleyen iletiler nelerdir?

4. Şermin Yaşar'ın çocuk kitaplarında yer alan evrensel gelişimi destekleyen iletiler nelerdir?

5. Şermin Yaşar'ın çocuk kitaplarında yer alan dinî gelişimi destekleyen iletiler nelerdir?

6. Şermin Yaşar'ın çocuk kitaplarında yer alan çevre bilinci gelişimini destekleyen iletiler nelerdir?

7. Şermin Yaşar'ın çocuk kitaplarında yer alan eğitsel iletilerin sunuluş biçimleri nasıldır?

\section{Yöntem}

Çalışmada Şermin Yaşar'ın çocuk kitaplarında yer alan eğitsel iletiler incelendiğinden çalışma nitel bir araştırmadır. Bağlamdaki anlama odaklanan nitel araştırmalar, veri toplama ve yorumlama sürecinde ele aldıkları araştırma konusu doğrultusunda anlamı ortaya çıkarmayı amaçlarlar (Merriam, 2018).

\section{Araştırmanın Deseni}

Bu çalışmada Şermin Yaşar'ın çocuk kitaplarındaki eğitsel iletilere odaklanılmış ve verilmek istenen iletiler ortaya çıkarılmaya çalışılmıştır. Çalışma, nitel araştırma yöntemlerinden durum çalışmasıyla desenlenmiştir. Durum çalışmasında amaç, belirlenen bir durumun derinlemesine incelenerek ve betimlemeler yapılarak oluşturulan anlam doğrultusunda sonuçlar ortaya koymaktır (Creswell, 2018). Çalışma durum çalışması desenlerinden iç içe geçmiş tek durum deseni olarak tasarlanmıştır. Bu desen, birden fazla alt tabaka veya birimi olan tek bir durumun birden fazla analiz birimine yönelmesi söz konusu olduğunda kullanılır (Yıldırım ve Şimşek, 2008). Bu çalışmada da öncelikle ele alınan kitaplardaki eğitsel iletiler incelenmiş ve sonrasında alanyazın taraması sonucu belirlenen kategoriler dikkate alınarak iletiler ayrı ayrı incelenip değerlendirilmiştir.

\section{Veri Kaynağı}

Çalışmanın veri kaynağını Şermin Yaşar'ın çocuk kitapları arasından 'Dedemin Bakkalı', 'Abartma Tozu', 'Oh Ne Ala Memleket', 'Babaannem Geri Döndü' adlı dokuz yaş ve üzeri çocuklar için yazıımış dört kitabı oluşturmaktadır. Çalışmanın veri kaynağı belirlenirken kitapların çocuk kitabı olması, dokuz yaş ve üzeri çocuklara yönelik olması, kitap sitelerinde okuyucular tarafından öneriliyor olması kıstasları dikkate alınmıştır. Bu sebeple veri kaynağı amaçlı örnekleme yöntemlerinden ölçüt örnekleme yöntemi kullanılarak belirlenmiştir. Ölçüt örnekleme yönteminde temel nokta önceden belirlenmiş olan ölçütleri karşılayan durumların seçilmesidir (Yıldırım ve Şimşek, 2008).

Veri kaynağını oluşturan kitaplara dair ayrıntılı bilgiler Tablo 1'de gösterilmiştir. 
Tablo 1.

Kitaplara Dair Tanıtıcı Bilgiler

\begin{tabular}{lccc}
\hline Kitap Adı & Yayınevi & Basım Yılı & Sayfa Sayısı \\
\hline Dedemin Bakkalı & Taze Kitap & 2019 & 200 \\
Abartma Tozu & Taze Kitap & 2019 & 159 \\
Oh Ne Ala Memleket & Doğan Egmont & 2021 & 165 \\
Babaannem Geri Döndü & Taze Kitap & 2021 & 160 \\
\hline
\end{tabular}

\section{Verilerin Toplanması}

Bu çalışmanın verileri nitel veri toplama yöntemlerinden doküman incelemesi yöntemi ile toplanmıştır. Doküman incelemesi, araştırılmasına karar verilmiş olay veya olgular hakkında bilgi içeren yazılı materyalleri ele alıp analiz eder (Yıldırım ve Şimşek, 2008). Bir çalışmada "doküman incelemesi belli başlı beş aşamada yapılabilir: Dokümanlara ulaşma, orijinalliğini kontrol etme, dokümanları anlama, veriyi analiz etme, veriyi kullanma" (Forster, 1995, aktaran Yıldırım ve Şimşek, 2008, s. 193). Bu çalışmada da bu aşamalar dikkate alınarak planlama yapılmıştır. Öncelikle çalışma kapsamında ele alınacak kitaplar araştırmacılar tarafından belirlendikten sonra kitap sitelerinden Tablo 1'de belirtilen Şermin Yaşar'ın dört kitabı temin edilip orijinallikleri kontrol edilmiştir. İlk iki aşama bittikten sonra çalışmada belirlenen amaç doğrultusunda kitapların dördü de ayrıntılı bir şekilde okunmuştur. Amaç doğrultusunda kitaplarda yer alan iletilerin varlığı, sıklı̆ı, türü, aktarılış şekli anlamlandırılmaya çalışılmıştır. Kitaplardaki iletiler hakkında iyice fikir sahibi olunduktan sonra analiz aşamasına geçilmiştir. İçerik analizi ile veriler analiz edildikten sonra elde edilen bulgular yorumlanmıştır.

\section{Verilerin Analizi}

Çalışmada elde edilen veriler içerik analizi ile analiz edilmiştir. İçerik analizinde amaç, elde edilen verileri derin bir işleme tabi tutarak bu verileri açıklayabilecek kavramları ve ilişkileri ortaya çıkarmaktır (Yıldırım ve Şimşek, 2008). Bu çalışmada da Şermin Yaşar'ın 'Dedemin Bakkalı' (DB), 'Abartma Tozu' (AT), 'Oh Ne Ala Memleket' (ONAM) ve 'Babaannem Geri Döndü' (BGD) kitaplarında yer alan eğitsel iletilerin amaçlarını ve sunuluş biçimlerini tespit etmek amacıyla derinlemesine bir inceleme yapılmıştır. Bunun için öncelikle alanyazın taraması yapılmış, eğitsel iletiler üzerine yapılan çalışmalar ve bu konuda yazılmış eserler incelenmiş, sonrasında da kitaplarda yer alan eğitsel iletiler kodlanmaya başlanmıştır. Kodlamada amaç, "eldeki verilerden anlam çıkarmak, onları metin veya görsel parçalara ayırmak, bu parçaları kodlarla etiketlemek, kodlamaların çakışıp çakışmadıklarını ya da gereksiz yere kullanılıp kullanılmadıklarını inceleyip bu kodları geniş temalarla daraltmaktır" (Creswell, 2017, s. 314-315). Dört kitabın da kodlama süreci bittikten sonra temaların oluşturulma sürecine geçilmiştir. Ancak kodlamalar yapılırken kitaplar cümle cümle okunup var olan tüm iletiler kendi geçtiği bağlamda ele alınarak çalışmaya dâhil edilmiştir. Yapılan kodlamalarda ortaya çıkan veriler neticesinde alanyazında yapılımıs olan benzer çalışmalarda oluşturulan temaların uygun olanlarının bu çalışma kapsamında da kullanılabileceği görülmüştür. Bu doğrultuda iletilerin amaçları bakımından belirlenen kodların altı tema; iletilerin sunuluşu bakımından belirlenen kodların ise iki tema altında toplanmasına karar verilmiştir. Amaçları bakımından eğitsel iletiler şu temalar altında toplanmıştır: Kişisel gelişimi destekleyen iletiler (KGDi), toplumsal gelişimi destekleyen iletiler (TGDi), ulusal gelişimi destekleyen iletiler (UGDi), evrensel gelişimi destekleyen iletiler (EGDi), dinî gelişimi destekleyen iletiler (DGDi) ve çevre bilinci gelişimini destekleyen iletiler (ÇBGDi). Sunuluş biçimleri bakımından ise belirlenen temalar şunlardır: Dolaylı aktarılan iletiler ve doğrudan aktarılan iletiler (Akçay ve Baş, 2015; Cesur ve Baş, 2015; Kavak ve Baş, 2018; Tekin ve Büyükikiz, 2019). Yazar kitaplarında dolaylı olarak aktardığı iletilerde bazen doğrudan bazen de o durumun olumsuzu ya da abartılması ile bu çıkarımları yapmamızı sağlamaktadır. Bu sebeple analizlerde bu üç durum da dolaylı ileti olarak kabul edilmiştir. Mesela 'Abartma Tozu' kitabında "Biriniz 120 kilosunuz, biriniz 95! Nasıl sağlıklı yaşam?” (s. 10) örneğinde kilo ile sağlıklı yaşam zıtlığı üzerinden sağlıklı beslenme çıkarımı bulunulmakta ve bu zıtlık da dolaylı ileti olarak kabul edilmektedir. Kodlar temalara göre sınıflandırıldıktan sonra elde edilen bulgular tablolar ve grafiklerle sunulup yorumlanmıştır. Tablolarda kitaplarda yer alan eğitsel iletiler uygun temalar içerisinde gösterilerek frekans ve yüzdelik değerleri de verilmiştir. 


\section{Geçerlik ve Güvenirlik}

Nitel araştırmalarda araştırmacının sonuçlara nasıl ulaştığını ayrıntılı bir şekilde anlatması geçerliğin önemli ölçütlerindendir (Yıldııım ve şimşek, 2008). Bu çalışmada da verilerin toplanması ve analizi bölümlerinde süreçler ayrıntılı bir şekilde anlatılmıştır. Ayrıca geçerliğin sağlanması adına çalışma sürecinde alanyazındaki benzer çalışmalar dikkate alınmış, verilerin toplanması ve analizinde de rehber rolü görmüşlerdir (Miles ve Huberman, 1994, aktaran Yıldırım ve Şimşek, 2008). Nitel araştırmalarda tutarlılık ve güvenirliğin sağlanmasında başvurulan stratejilerden biri uzman incelemesidir (Merriam, 2018). Bu çalışmada da pilot bir çalışma olması adına araştırmacı tarafından öncelikle 'Dedemin Bakkalı' adlı kitap kodlanıp temalara göre sınıflandırılmıştır. Bu süreç bittikten sonra uzman görüşüne başvurulmuştur. Yapılan analizler incelenmiş, görüş farklılığı olan yerler üzerine konuşulmuş ve nasıl olması gerektiği konusunda ortak bir karara varılmıştır. Uzman görüşü doğrultusunda 'Dedemin Bakkalı' kitabı tekrar gözden geçirilip bulguları düzenlenmiş ve daha sonra diğer kitapların analizine geçilmiştir. Kitapların analizleri tamamlandıktan sonra tekrar uzman görüşüne başvurulmuştur. Uzman tarafından gerekli incelemeler yapılmış, farklı değerlendirilen yerler üzerine istişare yapılıp ortak karara bağlanmıştır. Uzmandan alınan dönütler doğrultusunda bulgular düzenlenip yorumlanmıştır. Bulgular bu hâliyle tekrar uzman görüşüne sunulmuş ve hem analizlerin sunumuna hem de yapılan yorumların gerçeği yansıtıp yansıtmadığına dair uzmanın görüşleri alınmış ve alınan dönütler doğrultusunda bulgulara son şekli verilmiştir. Nitel çalışmalarda veri analizlerinin yanı sıra yapılan yorumların da gerçeği yansıtıp yansıtmadığına dair bir uzmana sunulması güvenirliğin sağlanması açısından önemlidir (Ekiz, 2017). Çalışma esnasında yukarıdaki süreçler titiz bir şekilde yürütülerek çalışmanın geçerliği ve güvenirliği sağlanmaya çalışılmıştır.

\section{Araştırma ve Yayın Etiği}

Bu çalışmada "Yükseköğretim Kurumları Bilimsel Araştırma ve Yayın Etiği Yönergesi" kapsamında uyulması belirtilen tüm kurallara uyulmuştur. Yönergenin ikinci bölümü olan "Bilimsel Araştırma ve Yayın Etiğine Aykırı Eylemler" başlığı altında belirtilen eylemlerden hiçbiri gerçekleştirilmemiştir.

\section{Bulgular}

Bu bölümde Şermin Yaşar'ın 'Dedemin Bakkalı', 'Abartma Tozu', 'Oh Ne Ala Memleket', 'Babaannem Geri Döndü' adlı kitaplarında yer alan eğitsel iletilere, kullanım sıklıklarına ve sunuluş biçimlerine dair elde edilen bulgular sunulmuştur. Kitaplarda kişisel gelişimi destekleyen iletiler ve sıklıkları Tablo 2'de gösterilmiştir.

Tablo 2.

Kişisel Gelişimi Destekleyen Iletiler ve Sıklıklarına Dair Bulgular

\begin{tabular}{|c|c|c|c|}
\hline \multirow{2}{*}{ Kitaplar } & \multirow{2}{*}{ Eğitsel iletiler } & \multicolumn{2}{|c|}{ Toplam } \\
\hline & & $f$ & $\%$ \\
\hline DB & $\begin{array}{l}\text { girişimci olmak (28), kariyer planlaması yapmak (13), okumaya önem vermek } \\
\text { (12), işinin inceliklerini bilmek (10), kendini takdir etmek (10), sağılıklı } \\
\text { beslenmek (10), dürüst olmak (7), sevgiye değer vermek (7), temiz olmak, } \\
\text { temizliğe önem vermek (7), bir hedef belirlemek (6), doğru iletişim kurmak } \\
\text { (6), yalan söylememek (6), aklını kullanmak (5), araştırmacı bir kişiliğe sahip } \\
\text { olmak (5), düşünceli davranmak (5), işini iyi yapmak (5), hayal kurmak (5), } \\
\text { yardımsever olmak (5), nasihat etmek (4), sır saklamak (4), sorunlara çözüm } \\
\text { bulmak (4), tedbirli olmak (4), eğitimli olmak (3), fırsatçı olmamak, insanların } \\
\text { zor durumundan yararlanmamak (3), hakkını aramak (3), ileri görüşlü olmak } \\
\text { (3), işine değer vermek (3), kendini tanımak (3), öz eleştiri yapmak (3), özür } \\
\text { dilemek (3), teşekkür etmek (3), yaratıcı olmak (3), adaletli olmak (2), bilinçli } \\
\text { tüketici olmak (2), cömert olmak (2), değerlendirme yapmak (2), eleştiriye } \\
\text { açık olmak (2), iyi insan olmak(2), karar verme becerisine sahip olmak (2), }\end{array}$ & 249 & 29,9 \\
\hline
\end{tabular}


kararlı olmak (2), mahremiyete saygı duymak (2), merak etmek (2), öfke kontrolünü sağlamak (2), pişmanlık duymak (2), planlama yapmak (2), söz dinlemek (2), sözünde durmak (2), yeniliklere açık olmak (2), açık sözlü olmak (1), bencil olmamak (1), bilinçli olmak (1), dedikodu yapmamak (1), güler yüzlü olmak (1), hedefine ulaşmak (1), hoş görülü olmak (1), israf, ziyan etmemek (1), işini sevmek (1), kendine değer vermek (1), kıymet bilmek (1), kötü yürekli olmamak (1), lider olmak (1), ön yargılı olmamak (1), özgüvenli olmak (1), paylaşmak (1), sabırlı olmak (1)

hiçbir konuda aşırıya kaçmamak (83), sağlıklı yaşamak (spor ve beslenme) $228 \quad 27,3$ (12), iletişim diline dikkat etmek (9), pişman olmak (9), teknoloji bağımlısı olmamak (7), sorunlara çözüm bulmak (6), araştırmacı olmak (5), bilinçli olmak (5), ihtiyaç ve istekleri ayırt etmek (5), maddiyata önem vermemek (5), aç gözlü olmamak (4), işini sevmek ve iyi yapmak (4), bilinçli tüketici olmak (3), her şeye inanmamak (3), hırslı olmak (3), insanları kandırmamak (3), iyi insan olmak (3), mücadeleci olmak (3), yardım istemek (3), zamanı dengeli kullanmak (3), kararlı olmak (2), misafirperver olmak (2), temiz olmak, temizliğe önem vermek (2), okumaya önem vermek (2), bencil AT olmamak (2), bir konu hakkında bilgi sahibi olmak (2), ders çalışmak (2), eleştiriye açık olmak (2), geç kalmamak (2), fırsatçı olmamak, insanların zor durumundan yararlanmamak (1), aç gözlü olmamak (1), anlayışlı olmak (1), büyükleri örnek almak (1), cesur olmak (1), çalışmak ve çalışmaya değer vermek (1), dostluk kurmak (1), düşünceli davranmak (1), hakkından fazlasını almamak (1), israf etmemek (7), karşısındakine değer vermek (1), kendine inanmak (1), kendini tanımak (1), kibirli olmamak (1), özgüvenli olmak (1), sabırlı olmak (1), planlama yapmak (1), söylenenleri dikkate almak (1), şikâyet etmemek (1), takdir etmek (1), teselli etmek (1), verdiği sözü tutmak (1), yalan söylememek (1), yardımsever olmak (1)

hayal kurmak (54), hayallerini gerçekleştirmek (16), aldığı kararın yanlışlığını $227 \quad 27,2$ fark etmek (13), ders çıkarmak (11), dengeli ve sağlıklı beslenmek (10), bir işin zorluğunu fark etmek (8), her söylenene inanmamak (8), temiz olmak, temizliğe önem vermek (8), teşekkür etmek (7), eleştirel bakmak (6), öğrenmek ve öğrenmeye önem vermek (5), sorgulayıcı olmak (5), sorumluluk sahibi olmak (5), kendini tanımak (4), sorunlara müdahale etmek (4), teknoloji bağımlısı olmamak (4), güven duymak (3), izin istemek (3), kıymet bilmek (3), meraklı olmak (3), özgün olmak (3), sakin konuşmak (3), teknolojiden yararlanabilmek (3), yalan söylememek (3), başarılı olmak (2), doğru iletişim kurmak (2), hâlden anlamak (2), iyi insan olmak (2), işini sevmek (2), öz eleştiri yapmak (2), takdir etmek (2), tebrik etmek (2), adil olmak (1), çalışkan olmak (1), dengeli olmak (1), esprili olmak (1), hakkını savunmak (1), ikna olmak (1), kendini takdir etmek (1), kendinle dalga geçmek (1), kibar olmak (1), kitapları sevmek (1), merhametli olmak (1), özür dilemek (4), pes etmemek (1), pişman olmak (1), sorunlara çözüm bulmak (1), sözünde durmak (1)

iletişim diline dikkat etmek (14), bir şeyin değerini anlamak (12), meraklı ve $130 \quad$ 15,6 araştırmacı olmak (10), bir gerçeğin farkına varmak (8), kıymet bilmek (7), dedikodu yapmamak (6), ders çıkarmak (6), okumaya önem vermek (5), sağııkı beslenmek (5), temizliğe ve düzene önem vermek (5), sorunlara çözüm bulmak (5), teknolojiden yararlanabilmek (3), doğru iletişim kurmak (2), doğruyu örnek almak (2), dürüst olmak (2), hâlden anlamak (2), hayal kurmak (2), göz sağlığına dikkat etmek (2), güvenmek (2), kararlı olmak (2), kibar olmak (2), küfür etmemek (2), mahremiyete saygı duymak (2), özür 
dilemek (2), sorumluluk sahibi olmak (2), teknoloji bağımlısı olmamak (2), yardım almak (2), bilinçli olmak (1), çalışkan olmak (1), çocuk ruhlu kalmak (1), emeğe saygı göstermek (1), fedakâr olmak (1), iftira atmamak (1), ispiyoncu olmamak (1), işini iyi yapmak (1), kendini tanımak (1), ödevlerini yapmak (1), sakin olmak (1), takdir etmek (1), tedbir almak (1), umut etmek (1), yalan söylememek (1)

Tablo 2 incelendiğinde kitapların tümünde kişisel gelişimi destekleyen iletilere sıkça yer verildiği görülmektedir. Kişisel gelişime yönelik en çok 'Dedemin Bakkalı' (\%29,9), en az ise 'Babaannem Geri Döndü' $(\% 15,6)$ kitaplarında ileti bulunmaktadır. 'Abartma Tozu' (\%27,3) ve 'Oh Ne Ala Memleket' $(\% 27,3)$ kitaplarında ise iletilerin oranının yakın olduğu görülmektedir. Dört kitapta da kişisel gelişime yönelik en çok yer alan iletiler birbirinden farklıdır.

'Dedemin Bakkalı' kitabında en çok yer alan kişisel gelişimi destekleyen iletiler; 'girişimci olmak', 'kariyer planlaması yapmak', 'okumaya önem vermek', 'işinin inceliklerini bilmek', 'kendini takdir etmek' ve 'sağılıkı beslenmek'tir. En az yer alan iletiler ise 'açık sözlü olmak', 'bencil olmamak', 'bilinçli olmak', 'dedikodu yapmamak', 'güler yüzlü olmak', 'hedefine ulaşmak', 'hoş görülü olmak', 'israf, ziyan etmemek', 'işini sevmek', 'kendine değer vermek', 'kıymet bilmek', 'kötü yürekli olmamak', 'Iider olmak', 'ön yargılı olmamak', 'özgüvenli olmak', 'paylaşmak' ve 'sabırlı olmak'tır.

'Abartma Tozu'nda en çok yer verilen kişisel gelişimi destekleyen ileti 'hiçbir konuda aşırıya kaçmamak'tır. Ayrıca 'sağlıklı yaşamak (spor ve beslenme)', 'iletişim diline dikkat etmek' ve 'pişman olmak' iletilerine de çok yer verilmiştir. En az yer verilen kişisel gelişimi destekleyen iletiler: 'insanların zor durumundan yararlanmamak', 'aç gözlü olmamak', 'anlayışlı olmak', 'büyükleri örnek almak', 'cesur olmak', 'çalışmak ve çalışmaya değer vermek', 'dostluk kurmak', 'düşünceli davranmak', 'hakkından fazlasını almamak', 'israf etmemek', 'karşısındakine değer vermek', 'kendine inanmak', 'kendini tanımak', 'kibirli olmamak', 'planlama yapmak', 'söylenenleri dikkate almak', 'şikâyet etmemek', 'takdir etmek', 'teselli etmek', 'verdiği sözü tutmak', 'yalan söylememek' ve 'yardımsever olmak'tır.

'Oh Ne Ala Memleket' kitabında en çok bulunan kişisel gelişimi destekleyen ileti 'hayal kurmak'tır. Sonrasında ise 'hayallerini gerçekleştirmek', 'aldığı kararın yanlışlığını fark etmek', 'ders çıkarmak' ile 'dengeli ve sağlıklı beslenmek'tir. En az yer verilen iletiler: 'adil olmak', 'çalışkan olmak', 'dengeli olmak', 'esprili olmak', 'hakkını savunmak', 'ikna olmak', 'kendini takdir etmek', 'kendinle dalga geçmek', 'kibar olmak', 'kitapları sevmek', 'merhametli olmak', 'özür dilemek', 'pes etmemek', 'pişman olmak', 'sorunlara çözüm bulmak' ve 'sözünde durmak'tır.

'Babaannem Geri Döndü'de en çok yer verilen kişisel gelişimi destekleyen iletiler: 'iletişim diline dikkat etmek', 'bir şeyin değerini anlamak' ve 'meraklı ve araştırmacı olmak'tır. En az yer verilen iletiler: 'bilinçli olmak', 'çalışkan olmak', 'çocuk ruhlu kalmak', 'emeğe saygı göstermek', 'fedakâr olmak', 'iftira atmamak', 'ispiyoncu olmamak', 'işini iyi yapmak', 'kendini tanımak', 'ödevlerini yapmak', 'sakin olmak', 'takdir etmek', 'tedbir almak', 'umut etmek' ve 'yalan söylememek'tir.

Kişisel gelişimi desteklemeye yönelik bazı örnek iletilere aşağıda yer verilmiştir:

'Dedemin Bakkalı'nda yer verilen 'kariyer planlaması', 'pişman olmak' ve 'yanlışın farkına varmak' iletileri:

Öyleyse en doğru mesleği bulmalıydım. Etrafımdaki yetişkinleri izlemeye başladım. Yaptıkları iş, sıkıcılık durumları, işlerini sevip sevmedikleri, kazandıkları para, bana fikir verecekti. Bir liste hazırladım (s. 13).

Bazen bakkalda ellerim çok kirlenince, şampuanların kapağını açıp azıcık elime damlatıyor ve gidip çeşmede elimi yıkıyordum. Şimdi düşünüyorum da bir başkasına ait şampuandan azıcık almak çok iyi bir davranış değilmiş (s. 45).

Garip Mustafa yok mu, 50 gram 50 gram, canım çıkıyor tartarken verdim birer kilo yolladım. Bu adam da zengin diye ona yazdım. Sevap işte. Hayır yaptım. Hayır kendi paranla olur! Başkasının parasıyla hayır mı olur? (s. 51)

'Abartma Tozu' kitabında yer verilen "hiçbir konuda aşırıya kaçmamak" iletisi: 
Insanlar işten çıkıp alışverişe koşmaya, marketten alacaklarını abarttıkça abartmaya başladılar (s. 55).

Ama ne yapayım, çoooook seviyorum oğlumu. Kızlarımı da çok seviyorum. O yüzden onlara hiiiç iş yaptırmıyorum (s. 65).

'Oh Ne Ala Memleket'te yer alan 'hayal kurmak' ve 'fark etmek' iletileri:

Müdür olduğum hafta okul hayatım sona ermiş olabilir. Ama bu benim en büyük hayalimdi (s. 98).

...teneffüsleri elli dakikaya uzatmıstım fakat hayalimizdeki gibi olmadı. Ben de dâhil, hepimiz cahil cahil dolaşıyoruz (s. 109).

'Babaannem Geri Döndü' kitabında bulunan 'araştırmacı ve meraklı olmak' iletisi:

Sonra deneyler yapmaya kalkışıyorum. Bilirsiniz işte çeşitli şeyleri birbirine karıştırarak bir şeyler denemek. Mesela sirkeyle şampuanı karıştırdım (s. 10).

Söylemiştim deneme yanılma yoluyla öğreniyorum (s. 19).

Kitaplarda yer alan toplumsal gelişimi destekleyen iletiler ve sıklıkları Tablo 3'te sunulmuştur.

Tablo 3.

Toplumsal Gelişimi Destekleyen Iletiler ve Sıklıklarına Dair Bulgular

\begin{tabular}{|c|c|c|c|}
\hline \multirow{2}{*}{ Kitaplar } & \multirow{2}{*}{ Eğitsel iletiler } & \multicolumn{2}{|c|}{ Toplam } \\
\hline & & $f$ & $\%$ \\
\hline DB & $\begin{array}{l}\text { çocuklarla doğru iletişim kurmak (59), çocuğu anlamak (21), büyükleri } \\
\text { saymak (8), aileye ve sevdikleri değer vermek (6), örnek olmak (5), emeğe } \\
\text { saygı göstermek (4), değerleri unutmamak (3), gelenek ve görenekleri } \\
\text { yaşatmak (2), yardımlaşmak (2), eğitime önem vermek (1), eşitlik (1), empati } \\
\text { kurmak (1), komşuluk ilişkilerine değer vermek (1) }\end{array}$ & 114 & 27,1 \\
\hline AT & $\begin{array}{l}\text { çocuğa ve aileye zaman ayırmak (9), selamlaşma ifadeleri kullanmak (7), } \\
\text { çocukluğu yaşamak (5), aileye değer vermek ve sevmek (4), çocukla doğru } \\
\text { iletişim kurmak (4), çocuğu anlamak (4), değerleri unutmamak (4), barış ve } \\
\text { huzur içinde yaşamak (4), çocuğu başkaları ile kıyaslamamak (3), büyükleri } \\
\text { saymak (2), emeğe saygı göstermek (2), olaylardan ders çıkarmak (2), } \\
\text { yardımlaşmak (2), birbirinden etkilenmemek (1), dilek ve şikâyetlerini ilgili } \\
\text { yerlere bildirmek (1), empati kurmak (1), görevlilere yardımcı olmak (1) }\end{array}$ & 56 & 13,3 \\
\hline ONAM & $\begin{array}{l}\text { çocukla doğru iletişim kurmak (19), çocuğu anlamak (10), toplumun } \\
\text { düşüncelerine önem vermek (8), örnek olmak (5), selamlaşma ifadelerini } \\
\text { kullanmak (3), toplum kurallarına uymak (3), bayramlaşmak (2), eğitime } \\
\text { önem vermek (2), barış ve huzur içinde yaşamak (1), büyüklere saygılı olmak } \\
\text { (1), çocukları sevmek (1), değerleri unutmamak (1), empati kurmak (1), } \\
\text { selamlaşma (1) }\end{array}$ & 84 & 19,9 \\
\hline BGD & $\begin{array}{l}\text { farkındalık yaratmak (52), çocuğu anlamak (34), aile ile kaliteli zaman } \\
\text { geçirmek (19), çocukla doğru iletişim kurmak (12), büyüklere iyi davranmak } \\
\text { (9), çocukluğu yaşamak (8), aile büyüklerini sevmek ve saymak (7), büyüklere } \\
\text { değer vermek (7), çocuğa zaman ayırmak (7), aile içi iletişime önem vermek } \\
\begin{array}{llll}\text { (5), selamlaşma ifadelerini kullanmak } & \text { (3), kıyas yapmamak (2), alay } \\
\text { etmemek (1), empati kurmak (1) } & & \end{array}\end{array}$ & 167 & 39,7 \\
\hline Toplam & & 421 & 100 \\
\hline
\end{tabular}

Tablo 3'te yazarın dört kitabında da toplumsal gelişimi destekleyen iletilere yer verdiği görülmektedir. En çok 'Babaannem Geri Döndü' $(\% 39,7)$ ve 'Dedemin Bakkalı' $(\% 27,1)$ kitaplarında iletilere yer verilmiştir. 'Oh Ne Ala Memleket' $(\% 19,9)$ ve 'Abartma Tozu' $(\% 13,3)$ kitaplarında iletilerin daha az olduğu görülmektedir. 'Dedemin Bakkalı' ve 'Oh Ne Ala Memleket' kitaplarında en çok sunulan ileti 'çocukla doğru iletişim kurmak'tır. 'Abartma Tozu' kitabında da çocuk ön plandadır ve en çok 'çocuğa ve aileye zaman ayırmak' iletisi yer almaktadır. 'Babaannem Geri Döndü'de ise en çok 
'farkındalık yaratmak' iletisi bulunmaktadır. Dört kitapta da toplumsal gelişime yönelik iletilerin merkezinde çocuğun olduğu görülmektedir.

'Dedemin Bakkalı'nda en çok yer alan toplumsal gelişimi destekleyen iletiler: 'çocuklarla doğru iletişim kurmak', 'çocuğu anlamak'; en az yer alan iletiler ise 'eğitime önem vermek', 'eşitlik', 'empati kurmak' ve 'komşuluk ilişkilerine değer vermek'tir.

'Abartma Tozu'nda en çok yer verilen iletiler: 'çocuğa ve aileye zaman ayırmak' ve 'selamlaşma ifadeleri kullanmak'tır. En az yer verilen iletiler ise 'birbirinden etkilenmemek', 'dilek ve şikâyetlerini ilgili yerlere bildirmek', 'empati kurmak' ve 'görevlilere yardımcı olmak'tır.

'Oh Ne Ala Memleket' kitabında en çok yer alan iletiler: 'çocukla doğru iletişim kurmak', 'çocuğu anlamak' ve 'toplumun düşüncelerine önem vermek'tir. En az yer alan iletiler ise: 'barış ve huzur içinde yaşamak', 'büyüklere saygılı olmak', 'çocukları sevmek', 'değerleri unutmamak', 'empati kurmak' ve 'selamlaşma'tır.

'Babaannem Geri Döndü'de en çok bulunan iletiler: 'farkındalık yaratmak', 'çocuğu anlamak', 'aile ile kaliteli zaman geçirmek' ve 'çocukla doğru iletişim kurmak'tır. En az yer verilen iletiler ise 'alay etmek' ve 'empati kurmak'tır.

Toplumsal gelişimi desteklemeye yönelik kitaplarda bulunan iletilere örnekler aşağıda sunulmuştur:

'Dedemin Bakkalı' kitabında yer alan 'büyüklere saygılı olmak' ve 'çocuklarla doğru iletişim kurmak' iletileri:

Ama dedeme olan saygımdan, sevgimden ve ustama olan hürmetimden yüzüne vurmuyordum (s. 20).

"Çocukların Yetişkinlerle iletişimde Dikkat Etmesi Gereken Hassas Konular"

1. Madde: Yetişkinlerin çocuklara yaptıkları haksızlıkları, hataları görebilirsin. Yine de yüzlerine vurma. Inanmazlar. Çocuksun görmezden gel. Bırak kendilerini dünyanın en zeki insanları sansınlar (s. 21).

'Abartma Tozu'nda yer alan 'çocuğa ve aile hayatına zaman ayırmak', 'değerleri unutmamak' ve 'yardımlaşmak' iletileri:

Eskiden az oyuncağım vardı ama birlikte oynayabilecek bir annem, babam vardı (s. 60).

Kendi çocuğunun farkına varmıyor ama başka çocukları telefon ekranından seviyordu. Önüne geçtim ve 'Anneeeee!' diye çığlık attım. Sonunda beni fark etti (s. 76).

Eskiden yardım etmek, nazik bir davranıştı, parayla yapılmazdı (s. 54).

'Oh Ne Ala Memleket'te bulunan 'toplum kurallarına uymak' iletisi:

Gııı Olduğum Şeyler Listesi'nde 11.madde bu: Insanların sıraya girmeyi beceremeyip birbirini ezmesi (s. 116).

'Babaannem Geri Döndü'de yer alan 'çocuğu anlamak' iletisi:

Öğretmenim tüm bunları onu sinir etmek için yaptığımı düşünüyor. Ama alakası yok. Sorun sadece canımın sıkılması (s. 9).

Ben böyleyim tamam mı? Böyleyim ben! Sizin yüzünüzden böyleyim! Siz sürekli beni uyarıorsunuz diye böyleyim (s. 117).

Kitaplardaki ulusal gelişimi destekleyen iletiler ve sıklıklarına dair bulgular Tablo 4'te gösterilmiştir.

Tablo 4.

Ulusal Gelişimi Destekleyen iletiler ve Sıklıklarına Dair Bulgular

\begin{tabular}{|c|c|c|c|}
\hline \multirow{2}{*}{ Kitaplar } & \multirow{2}{*}{ Eğitsel iletiler } & \multicolumn{2}{|c|}{ Toplam } \\
\hline & & $f$ & $\%$ \\
\hline DB & dil bilinci (3), ülke sevgisi (1) & 4 & 9,3 \\
\hline AT & dil bilinci, dili doğru kullanmak (12), yaşadığı yerin tarihini bilmek (2) & 14 & 32,6 \\
\hline ONAM & $\begin{array}{l}\text { millî bayramları tanımak ve bayramlara önem vermek (8), Atatürk'e değer } \\
\text { vermek (4), büyüklerin kıymetini bilmek (1), dil bilinci, dili doğru kullanmak } \\
\text { (3), ülkesini sevmek (1) }\end{array}$ & 17 & 39,5 \\
\hline
\end{tabular}




\begin{tabular}{llcc}
\hline BGD & dil bilinci, dili doğru kullanmak (8) & 8 & 18,6 \\
\hline Toplam & 43 & 100 \\
\hline
\end{tabular}

Tablo 4'te dört kitapta da ulusal gelişimi destekleyen iletilerin bulunduğu görülmektedir. Dört kitapta toplam 43 kez ulusal gelişime yönelik iletiye yer verilmiştir. 'Oh Ne Ala Memleket' $(\% 39,5)$ ve 'Abartma Tozu' $(\% 32,6)$ kitaplarında diğer kitaplara oranla ulusal gelişime yönelik daha fazla ileti bulunmaktadır. Kitapların tümünde 'dil bilinci', 'dili doğru kullanmak' iletilerinin ele alındığı görülmektedir. 'Oh Ne Ala Memleket' kitabında diğer kitaplara oranla ulusal gelişimi destekleyen daha farklı iletilere de yer verilmiştir. Bunlar: 'millî bayramları tanımak ve bayramlara yer vermek', 'Atatürk'e değer vermek', 'büyüklerinin kıymetini bilmek'tir. 'Ülke sevgisi' iletisinin 'Dedemin Bakkalı' ve 'Oh Ne Ala Memleket' kitaplarında yer aldığı görülmektedir.

Ulusal gelişimi desteklemeye yönelik iletilerden bazı örnekler aşağıda sunulmuştur:

'Abartma Tozu' kitabında yer alan 'dil bilinci, dili doğru kullanma' iletisi:

Bozulma böyle bir şey çünkü Tevfik Abi. Bir kişi yanlış konuşursa herkes yanlış konuşmaya başlıyor zamanla (s. 116).

Buğdaylı Sağlık Ocağı tabelasını indirmişler, yerine Buğdaylı Hospital yazan tabela koymuşlar (s. 124).

'Oh Ne Ala Memleket'te yer verilen 'millî bayramları tanımak ve bayramlara önem vermek', 'Atatürk'e değer vermek' ve 'büyüklerin kıymetini bilmek' iletileri:

Çocuklar, bu yıl 23 Nisan'ın yüzüncü yılını kutlayacağız. Biliyorsunuz, her sene 23 Nisan'da çocuklar bir günlüğüne büyüklerin yerine geçer (s. 27).

Iyi ki çocuğuz ve bir çocuk bayramımız var (s. 68). Bütün dünyada bir tek bize bayram (s. 68).

Her gün okula gidebiliyorsak, evlerimizde huzurla yaşayabiliyorsak, Türkçe konuşabiliyorsak; bunun sizin ve silah arkadaşlarınızın ve Kurtuluş Savaşı'nda sizinle birlikte olan herkesin sayesinde olduğunu biliyoruz (s. 44).

'Babaannem Geri Döndü' kitabında yer alan 'dil bilinci, dili doğru kullanma' iletisi:

Telefonla konuşurken sürekli 'aaanadın mı?' diyor. Sessiz harflerin yarısını kullanmıyor, seslileri de yanlış kullanıyor" (s. 18).

Ben aşırı kelimesini çok kullanırım. Babaannem de 'Bir şeyi beğendiysen 'çok güzel' de, 'aşırı' deme' derdi" (s. 48).

Kitaplarda evrensel gelişime yönelik yer alan iletiler ve sıklıklarına dair bulgular Tablo 5'te sunulmuştur.

Tablo 5.

Evrensel Gelişimi Destekleyen Iletiler ve Sıklıklarına Dair Bulgular

\begin{tabular}{llcc}
\hline \multirow{2}{*}{ Kitaplar } & \multirow{2}{*}{ Eğitsel iletiler } & \multicolumn{2}{c}{ Toplam } \\
\cline { 3 - 4 } & & dünya çocuklarını unutmamak (7), paylaşımcı olmak (6) & $\%$ \\
\hline DB & eşitlik (2) & 13 & 81,3 \\
\hline ON & barışı savunmak (1) & 2 & 12,5 \\
\hline BGD & - & 1 & 6,3 \\
\hline Toplam & & 16 & 100,1 \\
\hline
\end{tabular}

Tablo 5 incelendiğinde kitapların sadece üçünde evrensel gelişimi desteklemeye yönelik iletilere yer verildiği görülmektedir. 'Babaannem Geri Döndü' kitabında evrensel gelişime yönelik bir iletiye yer verilmemiştir. Kitaplardan 'Dedemin Bakkalı'nda $(\% 81,3)$ en çok iletiye yer verilmiştir. Bu iletiler 'dünya çocuklarını unutmamak' ve 'paylaşımcı olmak'tır. 'Abartma Tozu' kitabında 'eşitlik', 'Oh Ne Ala Memleket'te ise 'barışı savunmak' iletilerine yer verilmiştir.

Evrensel gelişimi desteklemeye yönelik iletilerden bazı örnekler aşağıda sunulmuştur:

'Dedemin Bakkalı' kitabında yer alan 'dünya çocuklarını unutmamak' iletisi:

Afrika'daki çocuklara. Kandilse sadece bize mi kandil? Onlara da kandil (s. 127). 
'Abartma Tozu' kitabında bulunan 'eşitlik' iletisi:

Bana göre bütün çocuklar birbirinin aynısıdır Tevfik Abi. Insanlar, çocuklar birbirinden ayrılmaz. Herkes eşittir (s. 122).

Başka bir farkım yok (s. 123).

Kitaplarda dinî gelişimi desteklemeye yönelik yer alan iletiler ve sıklıkları Tablo 6'da gösterilmiştir.

Tablo 6.

Dinî Gelişimi Destekleyen iletiler ve Sıklıklarına Dair Bulgular

\begin{tabular}{llccc}
\hline \multirow{2}{*}{ Kitaplar } & \multicolumn{2}{c}{ Eğitsel iletiler } & \multicolumn{2}{c}{ Toplam } \\
\cline { 3 - 5 } & $\begin{array}{l}\text { ibadet etmek (10), hayır yapmak (6), dua etmek (5), dua ve Kur’an } \\
\text { DB } \\
\text { Öğrenmek (4), sevap-günah bilmek (2), beddua etmemek (1), kandil } \\
\text { kutlamak (1), tövbe etmek (1) }\end{array}$ & & \\
& şükretmek (2), ibadet etmek (1) & 3 & \\
\hline AT & dua etmek (2), ibadet etmek (1) & 3 & 7 \\
\hline ONAM & şükretmek (3), ibadet etmek (3), dua etmek (1) & 7 & 16,3 \\
\hline BGD & & 43 & 100,1 \\
\hline Toplam &
\end{tabular}

Tablo 6'da kitapların tümünde dinî gelişimi destekleyen iletilerin olduğu görülmektedir. Ancak 'Dedemin Bakkalı' (\%69,8) kitabında diğer kitaplara oranla daha fazla ileti mevcuttur. 'Babaannem Geri Döndü' (\%16,3), 'Abartma Tozu' (\%7) ve 'Oh Ne Ala Memleket' (\%7) kitaplarında dinî ileti oranları birbirine yakındır. 'Ibadet etmek' iletisi tüm kitaplarda, 'dua etmek' ise üç kitapta yer almaktadır. 'Dedemin Bakkalı' kitabında dinî gelişimi destekleyen 8 farklı iletiye yer verilirken diğer kitaplarda iki ya da üç farklı iletiye verilmiştir.

Dinî gelişimi destekleyen iletilere dair örneklere aşağıda yer verilmiştir:

'Dedemin Bakkalı' kitabında yer alan 'ibadet etmek' iletisi:

Öğlen 1'de uyanıp camiye gidiyor (s. 26). Sonra ikindi için tekrar camiye gidiyor (s. 27).

'Babaannem Geri Döndü' kitabında yer alan 'şükretmek' ve 'ibadet edene saygı göstermek' iletileri:

O namazdayken, tespih çekerken falan konuşmaz, dikkatini dağıtmazdık (s. 91).

Ohhh be dedim, rüyaymış. Şükürler olsun (s. 137) sunulmuştur.

Kitaplarda yer alan çevre bilinci gelişimini destekleyen iletiler ve sıklıkları Tablo 7'de

Tablo 7.

Çevre Bilinci Gelişimini Destekleyen Iletiler ve Sıklıklarına Dair Bulgular

\begin{tabular}{|c|c|c|c|}
\hline \multirow{2}{*}{ Kitaplar } & \multirow{2}{*}{ Eğitsel iletiler } & \multicolumn{2}{|c|}{ Toplam } \\
\hline & & f & $\%$ \\
\hline DB & hayvanları sevmek (3) & 3 & 6,8 \\
\hline AT & doğayı korumak (11), hayvanları sevmek (2) & 13 & 29,5 \\
\hline ONAM & hayvanları sevmek (4), doğayı sevmek (1) & 5 & 11,4 \\
\hline BGD & $\begin{array}{l}\text { hayvanların sorumluluğunu üstlenmek (12), hayvanları tanımak ve } \\
\text { sevmek (6), doğayı tanımak ve sevmek (3), doğal afetleri tanımak (1), } \\
\text { hayvanları korumak (1) }\end{array}$ & 23 & 52,3 \\
\hline Toplam & & 44 & 100 \\
\hline
\end{tabular}

Tablo 7 incelendiğinde dört kitapta da çevre bilinci gelişimini desteklemeye yönelik iletilerin olduğu görülmektedir. Kitapların tümünde toplam 44 kez iletiye yer verilmiştir. 'Havyanları sevmek' iletisi dört, 'doğayı korumak/sevmek' iletisi ise üç kitapta yer almıştır. Çevre bilinci gelişimine yönelik 
iletiler en çok 'Babaannem Geri Döndü' $(\% 52,3)$ ve 'Abartma Tozu' $(\% 29,5)$ kitabındadır. En az ise 'Dedemin Bakkalı' $(\% 6,8)$ ve 'Oh Ne Ala Memleket' $(\% 11,4)$ kitabında yer almaktadır.

Çevre bilinci gelişimini desteklemeye yönelik iletilere dair bazı örnekler aşağıda verilmiştir:

'Abartma Tozu' kitabında yer alan 'doğayı korumak' iletisi:

Kasabanın içindeki yüzyılık ağaçları kesip yerine bina yaptılar. O binaların bahçelerine fidan dikip sitenin adını 'Orman Kent' koydular (s. 78).

Göller vardı kuruttular. Orman vardı, ağaçları kestiler (s. 110).

'Oh Ne Ala Memleket'te bulunan 'hayvan sevgisi' iletisi:

Öğretmenlerimiz senelerdir hayvan sevgisi deyip duruyorlardı. Biz neden sınıflarda tek başımıza eğitim görüyoruz? Elbette hayvan dostlarımıza da yer var (s. 124).

'Babaannem Geri Döndü' kitabında yer alan 'hayvanların sorumluluğunu üstlenmek' iletisi:

Ben de çocuklar istiyor diye ses etmez, sahiplenirdim... Onların da canı var. Iyi bakmak, gezdirmek, dolaştırmak lazım (s. 149). Kedileri ve köpeği barınaktan sahiplendim (s. 149).

Kitaplarda yer alan eğitsel iletilerin dağılımı Şekil 1'de gösterilmiştir.

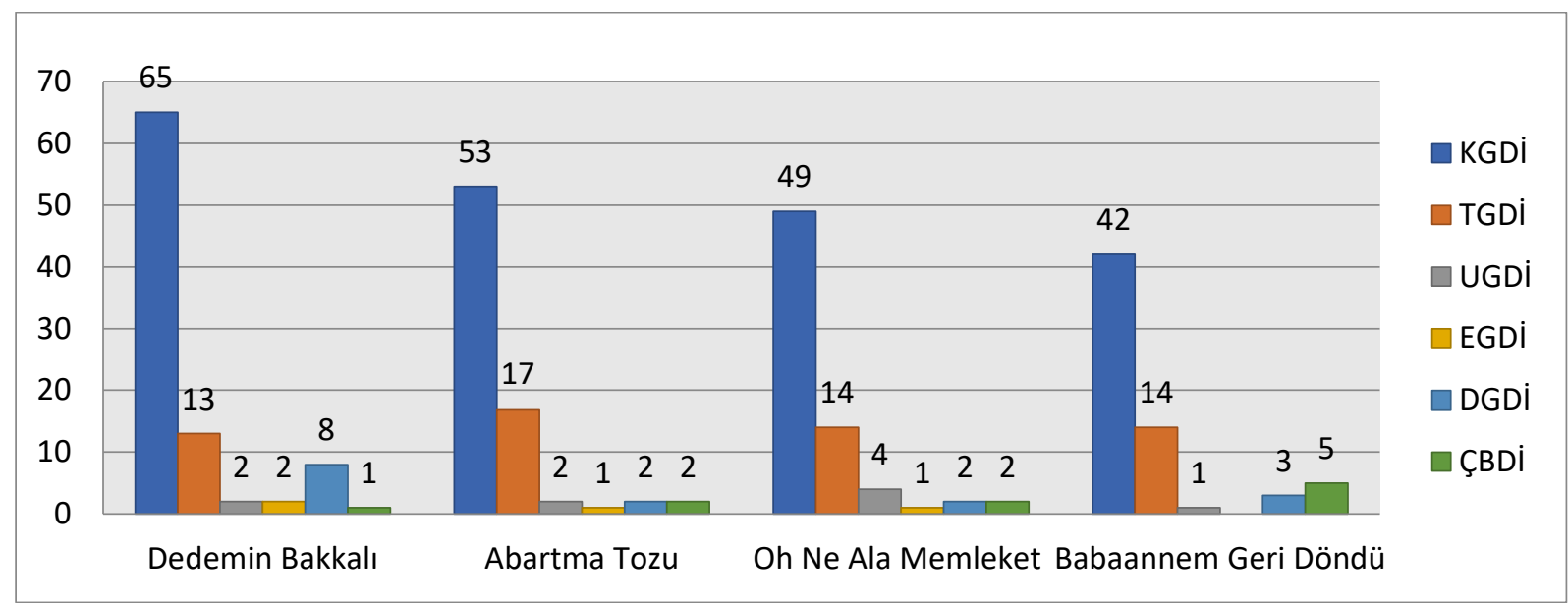

Şekil 1. Kitaplarda Yer Alan Eğitsel illetilerin Dağılımı

Şekil 1 incelendiğinde en fazla farklı eğitsel iletiye 'Dedemin Bakkalı' ( $f=91$ ); en az farklı iletiye ise 'Babaannem Geri Döndü' kitabında yer verildiği görülmektedir. Dört kitapta da kişisel gelişime yönelik daha fazla farklı ileti mevcuttur. Yine dört kitapta en az farklı iletinin ulusal, evrensel ve dinî gelişim ile çevre bilincini geliştirmeyi destekleyen iletilerde olduğu belirlenmiştir.

'Dedemin Bakkalı' adlı kitapta 65 kişisel, 13 toplumsal, 2 ulusal, 2 evrensel ve 8 dinî gelişim ile 1 çevre bilincini destekleyen iletiye rastlanmıştır. 'Abartma Tozu' kitabında 53 kişisel, 17 toplumsal, 2 ulusal, 1 evrensel ve 2 din gelişim ile 2 çevre bilincini destekleyen ileti bulunmuştur. Yazarın 'Oh Ne Ala Memleket' kitabında 49 kişisel, 14 toplumsal, 4 ulusal, 1 evrensel ve 2 dinî gelişim ile 2 çevre bilincini destekleyen iletiye rastlanmıştır. 'Babaannem Geri Döndü'de ise 42 kişisel, 14 toplumsal, 1 ulusal ve 3 dinî gelişim ile 5 çevre bilincini destekleyen iletiye rastlanmıştır, evrensel bilinci destekleyen iletilere ise rastlanmamıştır.

Kitaplarda yer alan eğitsel iletilerin tekrar edilme sıklığına dair bulgular Şekil 2'de gösterilmiştir. 


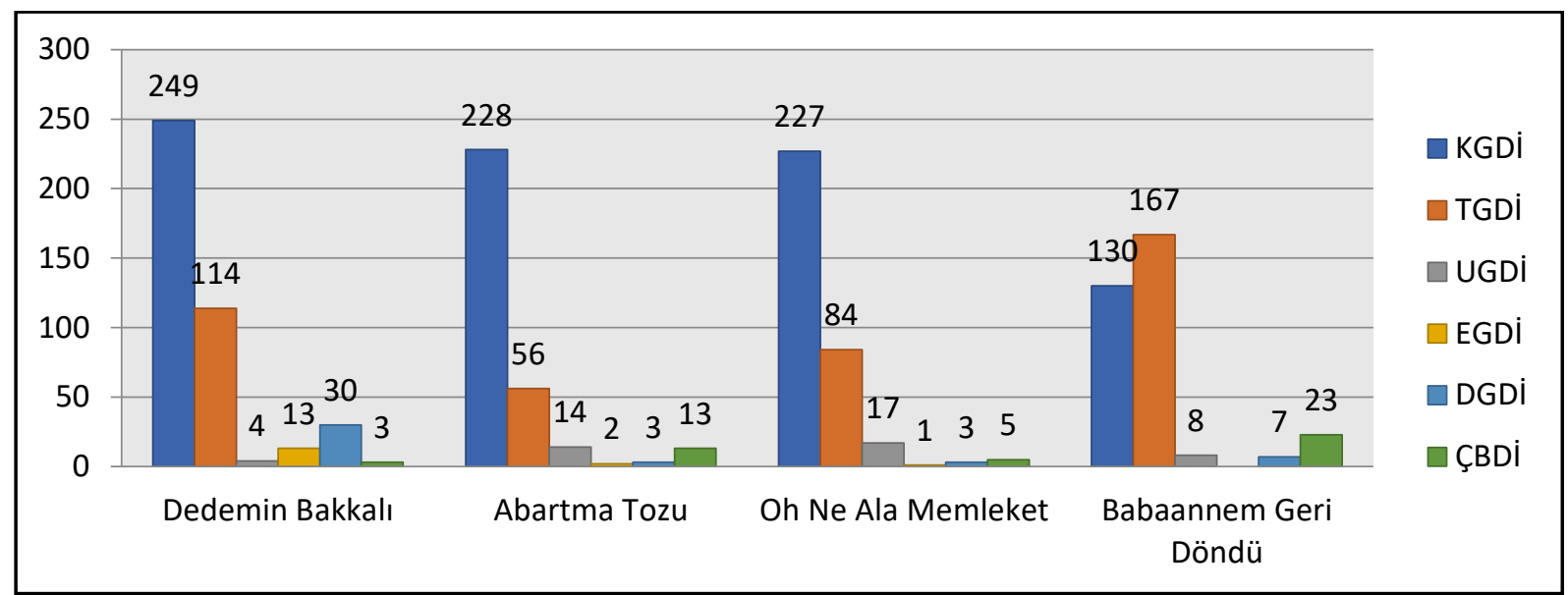

Şekil 2. Kitaplarda Yer Alan Eğitsel Illetilerin Tekrar Edilme Sıklığı

Şekilde 2'te en fazla eğitsel iletinin 'Dedemin Bakkalı' ( $f=413$ ) kitabında olduğu görülmektedir. 'Oh Ne Ala Memleket' ( $f=337)$, 'Babaannem Geri Döndü' ( $f=335)$ ve 'Abartma Tozu' ( $f=316)$ kitaplarındaki iletilerin oranları birbirine yakındır.

'Dedemin Bakkalı', 'Abartma Tozu' ve 'Oh Ne Ala Memleket' kitaplarında kişisel gelişimi destekleyen iletilerin tekrar edilme sıklığı daha fazladır. Üç kitapta da ikinci sırada toplumsal iletiler yer almaktadır. 'Babaannem Geri Döndü' kitabında ise toplumsal gelişimi destekleyen iletilerin daha sık tekrarlandığı görülmektedir. Bu kitapta kişisel gelişimi destekleyen ileti sayısı fazla olmasına rağmen tekrar sıklığı bakımından ikinci sıradadır. Evrensel, ulusal ve dinî gelişim ile çevre bilicini destekleyen iletiler kitaplarda az kullanılmakla beraber tekrarlanma sıklıkları da düşüktür.

Kitaplarda yer alan iletilerin aktarılış biçimi yönünden dağılımı Şekil 3'te sunulmuştur.

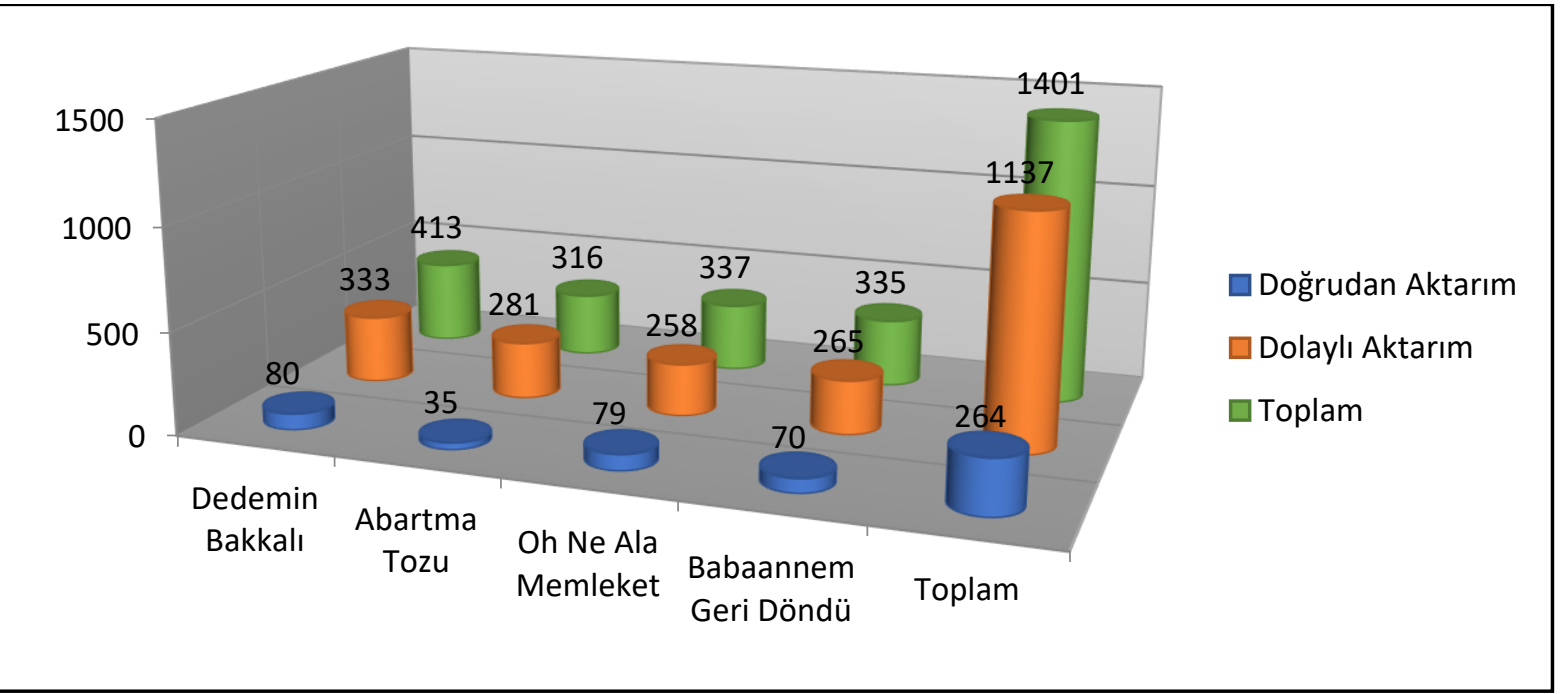

Şekil 3. Kitaplardaki Eğitsel İletilerin Aktarııış Biçimi Yönünden Dağılımı

Şekil 3'te yazarın dört kitapta da eğitsel iletilerin büyük bir kısmını dolaylı olarak $(\% 81,2)$ aktardığı görülmektedir. İletilerin çok az bir kısmını doğrudan aktardığı $(\% 18,8)$ belirlenmiştir. Özellikle 'Abartma Tozu' kitabında doğrudan aktarılan ileti sayısının çok az olduğu görülmektedir. Diğer üç kitapta doğrudan aktarılan iletilerin sayısı birbirine yakındır.

\section{Tartışma, Sonuç ve Öneriler}

Kitaplar çocukların duygu ve düşünce dünyasını geliştiren ögeler arasında yer almaktadır. Okuduklarından yola çıkarak çocuk; kafasında doğru-yanlış, iyi-kötü, güzel-çirkin gibi kavramları oluşturmaktadır. Bu sebeple çocukların okuduğu kitapların çocuklara doğru iletiler sunması 
gerekmektedir. Bu çalışmada Şermin Yaşar'ın çocuklara yönelik yazmış olduğu 'Dedemin Bakkalı', 'Abartma Tozu', 'Oh Ne Ala Memleket' ve 'Babaannem Geri Döndü' kitaplarında yer alan eğitsel iletiler incelenmiştir.

Çalışmada Şermin Yaşar'ın incelenen dört kitabında toplam 1401 kez eğitsel iletiye ver verildiği belirlenmiştir. Eğitsel iletilerin en fazla 'Dedemin Bakkalı' ( $f=413)$, en az ise 'Abartma Tozu'nda ( $f=316)$ olduğu belirlenmiştir. 'Oh Ne Ala Memleket' ( $f=337$ ) ve 'Babaannem Geri Döndü' (335) kitaplarında ise iletilere yer verme oranının birbirine oldukça yakın olduğu tespit edilmiştir. Bu bakımdan Yaşar'ın, kitaplarında eğitsel iletilere sıkça yer verdiğini söylemek mümkündür. Yazarın çoğu zaman mizahı da işin içine katarak dolaylı bir şekilde bunu yaptığı söylenebilir. Kitaplarında mümkün olduğunca didaktik bir anlatımdan uzak durduğu görülmektedir. Çalışmada elde edilen iletilerin sunuluş biçimine dair bulgular da bunu desteklemektedir. Çalışma sonucunda dört kitapta yer alan iletilerin 1137'sinin $(\% 81,2)$ dolaylı ve 264 tanesinin $(\% 18,8)$ doğrudan aktarıldığı tespit edilmiştir. Bu açıdan yazar doğrudan okuruna mesaj vermek yerine okurunun okuduklarını yorumlamasını ve bir çıkarımda bulunmasını istemektedir. Zira Sever (2019) tarafından da çocuk kitaplarında, çocukların neden-sonuç ilişkisi içinde düşünmesine mani olacak emir ve kurallardan oluşan cümlelere yer verilmemesi gerektiği vurgulanır. Yaşar'ın da kitaplarında buna dikkat ettiği görülmektedir. "Sağlıklı beslen, abur cubur tüketme" demek yerine 'Oh Ne Ala Memleket' kitabında abur cubur tüketimindeki kısıtlamaları eleştiren kahramanlar fazla abur cubur tüketip soluğu hastanede almaktadır. Böylece çocuğa bir olayın olası sonuçları üzerinden ders verilmektedir. Ancak burada verilmek istenen mesajları tamamen çocuğun çıkarması beklenir. Ayrıca alanyazında da eğitsel iletiler açısından incelenen çocuk kitaplarında iletilerin çoğunlukla dolaylı yoldan aktarıldığı görülmektedir (Akçay ve Baş, 2015; Cesur ve Baş, 2015, Kavak ve Baş, 2018; Tekin ve Büyükikiz, 2019).

Çalışmada 'Dedemin Bakkalı' kitabında 91, 'Abartma Tozu'nda 77, 'Oh Ne Ala Memleket'te 72 ve 'Babaannem Geri Döndü'nde 65 farklı eğitsel ileti tespit edilmiştir. En çok ileti 'Dedemin Bakkalı', en az ileti ise 'Abartma Tozu' kitabında belirlenmiştir. Genel olarak bakıldığında yazarın kitaplarında çocuklara çeşitli açılardan eğitsel iletiler sunduğu görülmektedir. Bu bakımdan çeşitliliğin çokça olduğu söylenebilir. Yaşar'ın 'Babaannem Geri Döndü' kitabı hariç diğer üç kitabında yer alan eğitsel iletilerin çocukların kişisel, toplumsal, ulusal, evrensel, dinî ve çevre bilinci gelişimlerini desteklemeye yönelik iletiler olduğu görülmüştür. 'Babaannem Geri Döndü' kitabında evrensel gelişimi destekleyen bir ileti bulunmamakla beraber diğer beş amaca yönelik iletilerin bulunduğu tespit edilmiştir. Yaşar'ın 'Dedemin Bakkalı', 'Abartma Tozu' ve 'Oh Ne Ala Memleket' adlı kitaplarında en çok çocukların kişisel gelişimini ve sonrasında toplumsal gelişimlerini destekleyen iletilerin yer aldığı görülmüştür. Ancak 'Babaannem Geri Döndü' kitabında çocukların en çok toplumsal gelişimini devamında kişisel gelişimini desteklemeye yönelik iletilerin olduğu belirlenmiştir. Alanyazında benzer çalışmalarda ele alınan çocuk kitaplarında da kişisel gelişimi destekleyen iletilerin diğer iletilerden daha fazla olduğu, ikinci sırayı ise toplumsal gelişimi destekleyen iletilerin aldığı görülmüştür (Acele, 2019; Akçay ve Baş, 2015; Cesur ve Baş, 2015; Gül, 2019; Kavak ve Baş, 2018; Tekin ve Büyükikiz, 2019). Bu yönüyle yazarın kitapları diğer araştırmalarda incelenen çocuk kitapları ile benzerlik göstermekte, çocukların kişilik gelişimini öncelikli olarak desteklemeyi hedeflemektedir. Ayrıca toplumsal iletilerin ikinci sırada yer alması ile çocuğun toplumun bir parçası olduğu da unutulmamaktadır. Ancak Yaşar'ın kitaplarında ulusal, evrensel, dinî ve çevre bilinci gelişimini destekleyen eğitsel iletilere çok daha az yer verdiği görülmüştür. Bunun sebebi seçtiği olayların daha çok çocuk kahramanların kendi küçük dünyalarında geçiyor olmasından ve çocuk ile çevresi etrafında şekillenmesinden kaynaklanıyor olabilir. Nitekim bu sonuç alanyazındaki benzer çalışmaların sonuçlarıyla da paralellik göstermektedir (Akçay ve Baş, 2015; Cesur ve Baş, 2015; Tekin ve Büyükikiz, 2019).

Kişisel gelişimi destekleyen iletiler açısından bakıldığında en çok iletiye 'Dedemin Bakkalı' ( $f=249)$, en az ise 'Babaannem Geri Döndü' $(\mathrm{f}=130)$ kitabında yer verildiği görülmüştür. 'Dedemin Bakkalı' kitabında 'girişimci olmak', 'Abartma Tozu' kitabında 'aşırıya kaçmamak', 'Oh Ne Ala Memleket' kitabında 'hayal kurmak' ve 'Babaannem Geri Döndü' kitabında 'iletişim diline dikkat etmek' iletilerinin en sık tekrarlanan kişisel gelişimi destekleyen iletiler olduğu belirlenmiştir. Bu da yazarın her kitabında farklı bir konu ele alarak çocukların kişisel gelişimlerine değişik açılardan katkı sağlamaya çalıştığı şeklinde yorumlanabilir. Ancak kitaplarda özellikle vurgulanan kişisel iletiler farklı olmakla 
birlikte 'sağlıklı beslenmek', 'okumaya önem vermek' ve 'temiz olmak' gibi yazarın her kitabında yer verdiği iletiler de bulunmaktadır. Tüm bu iletilere bakıldığında günümüz eğitim sisteminin yetiştirmeyi amaçladığı bireylerde olmasını istediği özellikleri Yaşar’ın kitaplarında ele aldığı söylenebilir. Örneğin 'Dedemin Bakkalı' kitabında en çok yer verilen girişimci olmak iletisinin Millî Eğitim Bakanlığı tarafından hazırlanan ders programlarında da vurgulandığı görülmektedir. 2019 Türkçe Dersi Öğretim Programı'nda da buna vurgu yapılır ve programda belirlenen 'Kişisel Gelişim' ve 'Bilim ve Teknoloji' temalarında girişimciliğe yer verildiği görülür (Millî Eğitim Bakanlığı [MEB], 2019). Keza Türkiye Yeterlilikler Çerçevesinde belirlenen sekiz anahtar yetkinlikten biri girişimci olmaktır, bir diğeri ise yazarın 'Babaannem Geri Döndü' kitabında en çok yer verdiği 'iletişim diline dikkat etmek' iletisi ile paralel olan ana dilinde iletişim yetkinliğidir (MEB, 2019). Bu bakımdan yazarın kitaplarında ön plana çıkan eğitsel iletilerin günümüz eğitim sisteminin hedefleri ile paralel olduğunu söyleyebiliriz. Alanyazında Türkçe ders kitaplarındaki öyküleyici metinlerinde yer alan eğitsel iletileri inceleyen Türkben (2019) de metinlerin çocuğun girişimciliği destekleyen metinler olduğunu tespit etmiştir.

Toplumsal iletişimi destekleyen iletiler açısından bakıldığında en çok iletinin 'Babaannem Geri Döndü' ( $f=167$ ), en az ise 'Abartman Tozu' ( $f=56)$ kitabında yer aldığı belirlenmiştir. 'Dedemin Bakkalı' ve 'Oh Ne Ala Memleket' kitaplarında 'çocukla doğru iletişim kurmak' ve 'Abartma Tozu' kitabında 'çocuğa ve aileye zaman ayırmak' iletileri ön plana çıkarılmıştır. Sadece 'Babaannem Geri Döndü' kitabında vurgulanan ileti 'farkındalık yaratmak' olup doğrudan çocuğu içeren bir ileti değildir. Zira yazar bu kitabında çocukların yanı sıra büyüklere de çeşitli iletiler verir. Çocuk gibi davranan babaanne kendi çocuklarına "siz de çocuktunuz, böyle şeyler yapıyordunuz, unutmayın" mesajını verirken babaannenin aşırılıklarına katlanan ebeveynler de "yaşlılara karşı sabırlı ve anlayışlı olmalıyız" mesajını vermektedir. Bu bakımdan sunduğu iletiler ile diğer kitaplardan da farklılaşmaktadır. Alanyazına bakıldığında ise Akçay ve Baş (2015) Samed Behrengi'nin hikâyelerinde en çok ön plana çıkarılan toplumsal gelişimi destekleyen iletilerin 'birlik ve beraberlik sağlamak' ile 'toplumsal eşitlik' olduğunu belirlemişlerdir. Tekin ve Büyükikiz (2019) ise Aytül Akal'ın çocuk kitaplarında en çok vurgulanan toplumsal gelişimi destekleyen iletinin 'yardımsever olmak' olduğunu tespit etmişlerdir. Bu bakımdan Yaşar'ın çocuk kitaplarında toplumsal gelişimi destekleyen iletilerin diğer yazarlardan ayrıldığı, toplum içerisinde çocuğu daha ön plana çıkarmaya çalıştığı söylenebilir. Nitekim Taşdelen (2005) alanı ve sınırı çocuk olan ve asıl gayesi çocuğun dünyasının anlaşııması olan çocuk edebiyatını çocuğu anlayan edebiyat olarak ifade eder ve çocuk edebiyatçısının asıl görevinin çocukluğu bir metin hâline getirmek olduğunu söyler. Bu sebeple de bir çocuk edebiyatı yazarının çocukluktan uzak durmaması gerektiğini vurgular. Zira Yaşar da 'çocuğu anlamak' ve 'çocukla doğru iletişim kurmak' iletilerine dört kitabında da yer vermiştir ve çocuğun gözünden yetişkinleri anlatmıştır. Öyle ki 'Dedemin Bakkalı' kitabı doğrudan çocukluk anılarından oluşmaktadır. Bu kitapta çocuk davranışlarını anlamaya çalışmayan yetişkinler, çocuğun (yazarın kendisidir) yetişkinlerin engeline takılan girişimcilik deneyimleri ve çocuk gözünden yetişkin davranışları anlatılmıştır. 'Abartma Tozu' kitabında bireysel başlayan aşırılıklar ve abartılarla toplumdaki değişimler ve yozlaşmalar anlatılmıştır. 'Oh Ne Ala Memleket' kitabında çocukları anlamaya çalışmayan, onların fikirlerini sormayan yetişkinler ele alınmış, çocukların deneme yanılma yolu ile doğruyu nasıl buldukları ve çocuğu anlayıp doğru bir iletişim kurunca sorunların nasıl çözüldüğü gösterilmiştir. 'Babaannem Geri Döndü'nde ise çocuklarını anlayıp onlarla doğru iletişim kuramayan ebeveynlere babaanne üzerinden çocukluk günleri hatırlatılmış, çocukla ve aile ile kaliteli zaman geçirildiğinde sorunların çözüldüğü görülmüştür. Bunlar dışında yazar 'çocuğa ve aileye zaman ayırmak', 'çocuklar arasında kıyas yapmamak', 'çocukla ve aile ile kaliteli zaman geçirmek', 'çocukluğu yaşamak' gibi iletilere de kitaplarında sıkça yer vermektedir. Bu açılardan kahramanları çocuklar olan, çocukların başından geçen olayları konu edinen bu kitaplar bir çocuk kitabı gibi durmasına rağmen yetişkinlere de hitap etmektedir. Bu yönden bakıldığında "nitelikli çocuk edebiyatı örnekleri yetişkin edebiyat okuru tarafından da okunabilmelidir" (Şirin, 2019, s. 36) görüşü ile uyuşmaktadır.

Ulusal gelişimi destekleyen iletiler açısından sonuçlara bakıldığında ise Türk Dili ve Edebiyatı Bölümü mezunu olan yazarın her kitabında 'dil bilinci', dili doğru kullanmak' iletisine yer verdiği belirlenmiştir. Dildeki bozulmalar, dili doğru kullanmamak iletisine "Abartma Tozu" kitabında yazarın daha fazla değindiği, aynı zamanda dili koruma vurgusu da yaptığı görülmektedir. Alanyazın incelendiğinde Mavisel Yener'in de çocuğun ulusal gelişimini desteklemek adına çocukta dil bilinci 
oluşturmaya katkı sağlayacak iletilere öykülerinde yer verdiği görülmüştür (Cesurve Baş, 2015). Yazarın 'Oh Ne Ala Memleket' kitabında da ayrıca 'Atatürk'e değer vermek' ve 'millî bayramlara önem vermek' iletilerine yer verdiği ve önemle üzerlerinde durduğu görülmüştür.

Evrensel gelişimi destekleyen iletiler açısından incelendiğinde ise kitaplarda en az rastlanan iletiler olduğu tespit edilmiştir. Bu sonuç alanyazındaki çalışmalarda ele alınan bazı çocuk kitapları ile benzerlik göstermektedir (Akçay ve Baş, 2015; Cesur ve Baş, 2015). Acele (2019) ve Gül'ün (2019) çalışmalarında ise evrensel iletilerin son sırada yer almadığı belirlenmiştir.

Dinî gelişimi destekleyen iletilerin de ulusal ve çevre bilinci gelişimini destekleyen iletilerle yakın oranda kitaplarda yer aldığı tespit edilmiştir. Dinî iletilerde 'ibadet etmek', 'şükretmek', 'hayır yapmak' gibi iletilere yer verilmiş, fakat bu iletilere diğer iletiler kadar yer verilmediği belirlenmiştir. Bu açıdan Akçay ve Baş'ın (2015) çalışması ile benzerlik göstermektedir. Ayrıca dinî iletiler ders verme amacı gütmeden olay döngüsü içinde yer almaktadır.

Çalışmadaki diğer bir sonuç ise çevre bilincini geliştirmeye yönelik iletiler; 'doğayı sevmek ve korumak', 'hayvanları sevmek ve korumak' ile 'sorumluluklarını üstlenmek' şeklinde farklı isimlerle ve çok olmamakla birlikte yazarın incelenen tüm kitaplarında mevcuttur. 'Babaannem Geri Döndü' kitabında sadece hayvan sevgisi değil, evcil hayvan edinmek isteyenlere bir hayvanın bakımı ile ilgili sorumluluklar da hatırlatılmaktadır. Koray Avcı Çakman'ın hikâyelerini inceleyen Kavak ve Baş (2018) eğitsel iletilerde kısmen farklı bir sınıflandırma yaparak hayvanları sevmek, doğal yaşamı sevmek ve doğayı/çevreyi korumak iletilerini sevgiye yönelik iletiler başlığı altında ele almışlardır. Bu kapsamda inceledikleri hikâyelerde yazarın insan sevgisinden sonra hikâyelerinde en sık yer verdiği iletinin hayvanları sevmek olduğunu; doğal yaşamı sevmek ve doğayı/çevreyi korumak iletilerine de yine sıkça yer verdiğini belirlemişlerdir. Cesur ve Baş (2015) ise Mavisel Yener'in kitaplarında kişisel gelişimi destekleyen iletiler arasında saydıkları sevgiye değer verme iletisinin içerisinde hayvan ve çevre sevgisini de ele aldığını tespit etmişlerdir Ayrıca çalışmalarında Mavisel Yener'in kitaplarında çevre bilinci oluşturmaya yönelik iletiler olduğunu da belirlemişler, ancak bu iletiyi ulusal gelişimi destekleyen iletiler sınıfına dâhil etmişlerdir. Tekin ve Büyükikiz (2019) de Aytül Akal'ın çocuk kitaplarında çevre bilinci geliştirmeye yönelik iletiler arasında doğanın değerini bilmek ve hayvanlara iyi davranmak iletilerinin olduğunu belirlemişlerdir. Bu da yazarların çocuklar için yazdıkları kitaplarda çevre ve doğa konularına duyarsız kalmadıklarını göstermektedir.

Sonuç olarak, Şermin Yaşar'ın bu çalışmada ele alınan dört çocuk kitabında da eğitsel iletilere sıkça yer verildiği ortaya çıkmıştır. Kitaplarda çocukların kişisel ve toplumsal gelişimini destekleyen iletilerin ağırlıkta olmakla beraber ulusal, evrensel, dinî ve çevre bilinci gelişimini de destekleyen iletilere yer verildiği belirlenmiştir. Ayrıca yazarın bu iletileri verirken didaktik bir anlatımdan uzak mizahi bir anlatıma sahip olduğu ve bu doğrultuda da iletilerin çoğunu dolaylı bir şekilde aktardığı belirlenmiştir. Yaşar'ın kitaplarında yer alan eğitsel iletilerin Millî Eğitim Bakanlı̆ı̆'nın yetiştirmeyi hedeflediği bireylerde olması gereken özelliklerle de benzerlik gösterdiği ortaya çıkmıştır.

Bu sonuçlardan hareketle şu önerilerde bulunulmuştur:

1. Çalışmada yazarın kitaplarında daha çok kişisel ve toplumsal iletilerin olduğu belirlenmiştir. Nitekim alanyazındaki çalışmalarda da benzer sonuçların olduğu görülmüştür. Bu sebeple çocuk kitabı yazacak olan yazarların diğer ileti türlerine de kitaplarında sıkça yer vermesi çocukların gelişimi açısından önemli bir ihtiyaçtır.

2. Günümüz dünyası özellikle çevre ve hayvan hakları konusunda önemli sorunlarla karşı karşıyadır. Bu sebeple çocuk kitaplarında bu konuların yazarlar tarafından daha sık ele alınmasına ihtiyaç vardır. Nitekim bu konulara yönelik duyarlıık çocuklara küçük yaşta kazandırılmalıdır. Aksi takdirde ileride kazandırılması pek mümkün olmamaktadır.

3. Çocuk edebiyatı çocuğun okuma alışkanlığı kazanması açısından önemlidir. Çocuklar kendini bulduğu, eğlendiği kitapları okumayı sever. Yazar mizahi ögelere kitaplarında sıkça yer verdiği ve olayları çocuk dili ve çocuk bakış açısı ile aktardığı için çocukların öğreticilik kaygısı taşımayan bu kitaplarla okuma alışkanlığı edinebilecekleri düşünülmektedir. Bu sebeple öğretmenler ve aileler okuma listelerine bu kitapları ekleyebilirler. 
4. Bu çalışmada Şermin Yaşar'ın dört kitabı incelenmiştir. Ancak yazar farklı yaş gruplarına yönelik de kitaplar yazmaktadır. Diğer araştırmacılar tarafından yazarın bu çalışmada ele alınmayan diğer kitapları da eğitsel iletiler açısından incelenebilir.

\section{Araştırma ve Yayın Etiği}

Bu çalışmada "Yükseköğretim Kurumları Bilimsel Araştırma ve Yayın Etiği Yönergesi" kapsamında uyulması belirtilen tüm kurallara uyulmuştur. Yönergenin ikinci bölümü olan "Bilimsel Araştırma ve Yayın Etiğine Aykırı Eylemler" başlığı altında belirtilen eylemlerden hiçbiri gerçekleştirilmemiştir.

\section{Yazarların Katkı Oranı}

Çalışmanın 1. yazarı \%50, 2. yazarı \%50 oranında çalışmaya katkı sağlamıştır.

\section{Çıkar Çatışması}

Çıkar çatışması teşkil edebilecek herhangi bir durum bulunmamaktadır.

\section{Kaynaklar}

Acele, M. (2019). Ibrahim Örs'ün çocuklara yönelik eserlerinin eğitsel iletiler açısından incelenmesi (Yayımlanmamış yüksek lisans tezi). Necmettin Erbakan Üniversitesi Eğitim Bilimleri Enstitüsü, Konya.

Akçay, S. ve Baş, B. (2015) Samed Behrengi'nin hikâyelerindeki eğitsel iletiler üzerine bir araştırma. Ana Dili Eğitimi Dergisi, 3(3), 77-90. DOI: 10.16916/aded.76227

Aral, N. ve Baran, G. (2011). Çocuk gelişimi. İstanbul:Ya-pa Yayın.

Arıcl, A. (2008). Okumayı niye sevmiyoruz üniversite öğrencileri ile mülakatlar. Mustafa Kemal Üniversitesi Sosyal Bilimler Enstitüsü Dergisi, 5(10), 92-100.

Canlı, S. ve Aslan, C. (2018). Çetin Öner'in "Gülübirlik" adlı çocuk romanının yapısal ve eğitsel ilkeler açısından incelenmesi. Illköğretim Online, 17(2), ss. 812-833.

DOI:10.17051/ilkonline.2018.419306

Cesur, E. ve Baş, B. (2015). Mavisel Yener'in çocuklara yönelik öykülerindeki eğitsel iletiler üzerine bir araştırma. Ana Dili Eğitimi Dergisi, 3(3), 64-76. DOI: 10.16916/aded.96055

Creswell, J. W. (2017). Eğitim araştırmaları (H. Ekşi, Çev. Ed.). İstanbul: Edam Yayınları.

Creswell, J. W. (2018). Nitel araştırma yöntemleri (B. Tütün ve S. B. Demir, Çev. Ed.). Ankara: Siyasal Kitabevi.

Çınar, ì. (2009). Çocuk kitaplarında bulunması gereken özellikler. Eğitiş̧im Dergisi, 22.

Dilidüzgün, S. (2004). Okuma öğretimi hedefleri bağlamında Türkçe ders kitaplarındaki çocuk edebiyatı ürünleri. Hasan Ali Yücel Eğitim Fakültesi Dergisi, 2, 43-55.

Ekiz, D. (2017). Bilimsel araştırma yöntemleri. Ankara: Anı Yayıncılık.

Gül, M. (2019). Nur İçözü’nün eserlerinde eğitsel iletiler (Yayımlanmamış yüksek lisans tezi). Erzincan Binali Yıldırım Üniversitesi Sosyal Bilimler Enstitüsü, Erzincan.

Günay, V. D. (2003). Metin bilgisi. İstanbul: Multilingual.

Kaplan, K. (2013). Hidayet Karakuş'un roman ve hikâyelerinde yer alan eğitsel iletiler (Yayımlanmamış yüksek lisans tezi). Afyon Kocatepe Üniversitesi Sosyal Bilimler Enstitüsü, Afyon.

Karahanoğlu, E. (2017). Sevinç Kuşoğlu'nun çocuk kitaplarında yer alan eğitsel iletiler (Yayımlanmamış yüksek lisans tezi). Uludağ Üniversitesi Ĕgitim Bilimleri Enstitüsü, Bursa.

Kavak, S. ve Baş, B. (2018). Koray Avcı Çakman'ın hikâyelerindeki eğitsel iletiler üzerine bir araştırma. Ana Dili Eğitimi Dergisi, 6(4), 1141-1159. DOI: 10.16916/aded.461083

Kavcar, C., Oğuzkan, F. ve Sever, S. (2005). Türkçe öğretimi Türkçe ve sınıf öğretmenleri için (7. baskı). Ankara: Engin Yayıncılık.

Köse, S. (2011). Muzaffer İzgü'nün "Anneannemin Akıl Almaz Maceraları" serisindeki eğitsel iletiler (Yayımlanmamış yüksek lisans tezi). Atatürk Üniversitesi Eğitim Bilimleri Enstitüsü, Erzurum. 
Kuru, H. (2018). Çetin Öner'in "Gülübik" adlı çocuk kitabında eğitsel iletiler. Mehmet Akif Ersoy Üniversitesi Sosyal Bilimler Enstitüsü Dergisi, 10(24), 323-329. DOI: 10.20875/makusobed.376750

Merriam, S. B. (2018). Nitel araştırma: desen ve uygulama için bir rehber (S. Turan, Çev. Ed.). Ankara: Nobel Yayıncilık.

Millî Eğitim Bakanlığı [MEB]. (2019). Türkçe dersi öğretim programı (illkokul ve ortaokul 1, 2, 3, 4, 5, 6, 7, 8. sınıflar). http://mufredat.meb.gov.tr adresinden edinilmiştir.

Sever, S. (2013). Çocuk edebiyatı ve okuma kültürü. İzmir: Tudem Yayınları.

Sever, S. (2019). Çocuk ve edebiyat. Ankara: Tudem.

Suna, Ç. (2006). ilköğretim öğrencilerinin okuma ilgi ve alışkanlıklarını etkileyen etmenlerin analitik olarak incelenmesi ve değerlendirilmesi (Yayımlanmamış yüksek lisans tezi). Anadolu Üniversitesi, Eğitim Bilimleri Enstitüsü, Eskişehir.

Şirin, M. R. (2019). Çocuk, çocukluk ve çocuk edebiyatı. İstanbul: Uçan At Yayınları.

Tanju, E. (2010). Çocuklarda kitap okuma alışkanlığına genel bir bakış. Sosyal Politika Çalışmaları Dergisi, 21(21), 30-39.

Taşdelen, V. (2005). Çocuk edebiyatı: çocuğu anlayan edebiyat. Hece Dergisi, 104/105, 319-331.

Tekin, A. ve Büyükikiz, K. K. (2019). Aytül Akal'ın çocuk kitaplarının eğitsel iletiler açısından incelenmesi. Okuma Yazma Eğitimi Araştırmaları, 7(2), 110-123. DOI: 10.35233/oyea.662748

Türk Dil Kurumu [TDK]. (2021). Güncel Türkçe sözlük. https://sozluk.gov.tr/ adresinden edinilmiştir.

Türkben, T. (2019). Türkçe ders kitaplarındaki öyküleyici metinlerin yapısal ve eğitsel ilkeler açısından incelenmesi. Insan ve Toplum Bilimleri Araştırmaları Dergisi, 8(3), 2027-2056.

Uzuner-Yurt, S. ve Şimşek, T. (2016). Sevim Ak'ın öykülerinin eğitsel iletileri. Ana Dili Eğitimi Dergisi, 4(4), 474-488.

Yardımcı, M. ve Tuncer, H. (2002). Eğitim fakülteleri için çocuk edebiyatı. Ankara: Ürün Yayıncılık.

Yıldııı, A. ve Şimşek, H. (2008). Sosyal bilimlerde nitel araştırma yöntemleri. Ankara: Seçkin Yayıncılık.

YıImaz, O. (2016). Çocuk kitaplarında bulunması gereken özellikler. Şimşek, T. (Ed.), Okul öncesinde çocuk edebiyatı ve medya el kitabı (ss. 61-108). Ankara: Grafiker Yayınları.

\section{Incelenen Kitaplar}

Yaşar, Ş. (2019). Dedemin bakkalı (13. baskı). Ankara: Taze Kitap.

Yaşar, Ş.(2019). Abartma tozu. Ankara: Taze Kitap.

Yaşar, Ş. (2021). Oh ne ala memleket. İstanbul: Doğan Egmont.

Yaşar, Ş. (2021). Babaannem geri döndü. İstanbul: Taze Kitap.

\section{Introduction}

\section{Extended Abstract}

Children's literature is defined as an educational type of literature that will help children recognize life, develop their imagination, and instill the love of reading in them (TDK, 2021). Children's literature plays an important role in enriching children's emotional and thought worlds. It is a guide for children in their journeys to discover themselves and life.

Children's books contribute to children's education by means of messages. Children's books should include messages that will allow children to realize their potential and add good feelings and values to them. For this reason, the messages in children's books are of importance. The messages to be received by children in the most important period of their development may play a decisive role in their future lives. Therefore, identification of the messages in the books children read is of importance in allowing not only educators and parents but also those working in the field to see what messages children face.

The aim of this study was to examine the educational messages in the books of Şermin Yaşar titled 'Dedemin Bakkalı', 'Abartma Tozu', 'Oh Ne Ala Memleket' and 'Babaannem Geri Döndü'. The following research questions were formulated to scrutinize the educational messages in those books:

1. What are the messages that support personal development in Şermin Yaşar's children's books?

2. What are the messages that support social development in Şermin Yaşar's children's books? 
3. What are the messages that support national development in Şermin Yaşar's children's books?

4. What are the messages that support universal development in Şermin Yaşar's children's books?

5. What are the messages that support regional development in Şermin Yaşar's children's books?

6. What are the messages supporting environmental consciousness in Şermin Yaşar's children's books?

7. What are the presentation types of educational messages in Şermin Yaşar's children's books?

\section{Method}

The study was designed as an embedded single-case design from case study designs. The data consisted of Şermin Yaşar's children's books titled 'Dedemin Bakkalı', 'Abartma Tozu', 'Oh Ne Ala Memleket' and 'Babaannem Geri Döndü'.

The data were collected via document analysis and analyzed through content analysis. Firstly, a review of the relevant literature was conducted by examining the studies on educational messages. Later, the educational messages in the selected books were coded. After the coding procedure, themes were formed. It was decided to collect the codes identified in terms of aims of messages under six themes while the codes specified regarding the presentation of messages were collected under two themes. The educational messages were categorized under the following themes in terms of their goals: the messages that support personal development, social development, national development, universal development, religious development, and the development of environmental consciousness. The themes specified regarding the presentation of messages were: Indirect messages and direct messages (Akçay and Baş, 2015; Cesur and Baş, 2015; Kavak and Baş, 2018; Tekin and Büyükikiz, 2019).

In qualitative research, one of the important criteria is validity in which the researcher explains in detail how s/he achieved the conclusions (Yıldırım and Şimşek, 2008). In this regard, the procedures were detailed for data collection and analysis in this study. In addition, similar studies in the literature were considered to provide validity and guided data gathering and analysis procedures (Miles and Huberman, 1994, cited in Yıldııım and Şimşek, 2008). One of the strategies used to ensure consistency and reliability in qualitative research is expert review (Merriam, 2018). The expert review was implemented after the examination of the books. Necessary examinations were performed by the expert, joint resolutions were provided upon consultation on issues that were evaluated differently. The findings were organized and interpreted per the feedback provided by the expert.

\section{Results and Discussion}

Based on the findings, a total of 1401 educational messages were found in Şermin Yaşar's books investigated in this study. It was determined that while the highest number of educational messages was in 'Dedemin Bakkalı' ( $f=413$ ), the book with the least number of messages was 'Abartma Tozu' ( $f=316)$. On the other hand, the books 'Oh Ne Ala Memleket' ( $f=337$ ) and 'Babaannem Geri Döndü' (335) had quite a similar number of educational messages. Therefore, it can be argued that Yaşar has frequently used educational messages in her books. However, the author gives messages indirectly by using humor most of the time. It is seen that she keeps away from a didactic narration in her books. The findings on the presentation of the messages obtained in the study also support this. Using a total of 1401 educational messages in her four books, the author was determined to give 1137 $(81,2 \%)$ of these messages indirectly and 264 of them (18,8\%) directly.

It was concluded that there were 91 educational messages in 'Dedemin Bakkalı', 77 in 'Abartma Tozu', 72 in 'Oh Ne Ala Memleket' and 65 in 'Babaannem Geri Döndü'. While the highest number of educational messages was in 'Dedemin Bakkalı', 'Abartma Tozu' was identified with the lowest number of educational messages. In general, it was observed that the author provided children with a diverse range of educational messages. It was seen that the educational messages in Yaşar's three books, except 'Babaannem Geri Döndü', were messages aimed at developing personal, social, national, universal, religious, and environmental consciousness development in children. Although there is no message supporting universal development in 'Babaannem Geri Döndü', the book consisted of messages regarding the other five purposes. In Yaşar's books 'Dedemin Bakkalı', 'Abartma Tozu' and 'Oh Ne Ala Memleket', most of the messages supported personal development in children, followed 
by messages supporting their social development. However, in 'Babaannem Geri Döndü' most of the messages support was for social development, followed by the messages supporting personal development. It was also identified in the prior studies that the messages supporting the personal development formed the majority in the children's books examined, followed by the messages supporting social development (Acele, 2019; Akçay and Baş, 2015; Cesur and Baş, 2015; Gül, 2019; Kavak and Baş, 2018; Tekin and Büyükikiz, 2019).

To conclude, it was found that Şermin Yaşar frequently used educational messages in her four books, discussed in this article. Although the messages supporting personal and social development in children were used more in the books, the messages supporting the development of national, universal, religious, and environmental awareness were also included. The author did not use a didactic style but humorous narration when providing these messages and conveyed most of the messages indirectly. The messages are similar to the desired individual characteristics aimed to be instilled in the curriculum prepared by the Ministry of National Education. 